\title{
An updated classification of the jumping plant-lice (Hemiptera: Psylloidea) integrating molecular and morphological evidence
}

\author{
Daniel BURCKHARDT ${ }^{1, *}$, David OUVRARD ${ }^{2} \&$ Diana M. PERCY $^{3}$ \\ ${ }^{1}$ Naturhistorisches Museum, Augustinergasse 2, 4001 Basel, Switzerland. \\ ${ }^{2}$ ANSES, Plant Health Laboratory, Entomology and invasive plants unit, \\ 755 avenue du campus Agropolis, CS 30016, 34988 Montferrier-sur-Lez Cedex, France. \\ ${ }^{3}$ Department of Botany, University of British Columbia, 6270 University Boulevard, \\ Vancouver V6T 1Z4, Canada. \\ ${ }^{*}$ Corresponding author: daniel.burckhardt@bs.ch \\ 2Email: david.ouvrard@anses.fr \\ ${ }^{3}$ Email: diana.percy@ubc.ca \\ ${ }^{1}$ urn:1sid:zoobank.org:author:2FA5C7E5-D28E-4220-9796-02717E892B1D \\ ${ }^{2}$ urn:lsid:zoobank.org:author:2748132A-5D53-4BBA-9E33-F2723DCAAF19 \\ ${ }^{3}$ urn:lsid:zoobank.org:author:84F3C908-9927-40A6-BBBF-6951B7736278
}

\begin{abstract}
The classification of the superfamily Psylloidea is revised to incorporate findings from recent molecular studies, and to integrate a reassessment of monophyla primarily based on molecular data with morphological evidence and previous classifications. We incorporate a reinterpretation of relevant morphology in the light of the molecular findings and discuss conflicts with respect to different data sources and sampling strategies. Seven families are recognised of which four (Calophyidae, Carsidaridae, Mastigimatidae and Triozidae) are strongly supported, and three (Aphalaridae, Liviidae and Psyllidae) weakly or moderately supported. Although the revised classification is mostly similar to those recognised by recent authors, there are some notable differences, such as Diaphorina and Katacephala which are transferred from Liviidae to Psyllidae. Five new subfamilies and one new genus are described, and one secondary homonym is replaced by a new species name. A new or revised status is proposed for one family, four subfamilies, four tribes, seven subtribes and five genera. One tribe and eight genera/subgenera are synonymised, and 32 new and six revised species combinations are proposed. All recognised genera of Psylloidea (extant and fossil) are assigned to family level taxa, except for one which is considered a nomen dubium.
\end{abstract}

Keywords. Sternorrhyncha, systematics, new taxa, new combinations, nomenclature.

Burckhardt D., Ouvrard D. \& Percy D.M. 2021. An updated classification of the jumping plant-lice (Hemiptera: Psylloidea) integrating molecular and morphological evidence. European Journal of Taxonomy: 736: 137-182. https://doi.org/10.5852/ejt.2021.736.1257

\section{Introduction}

Jumping plant-lice or psyllids constitute the superfamily Psylloidea Latreille, 1807 of the hemipterous Sternorrhyncha Duméril, 1806 with world-wide about 4000 described and at least as many undescribed 
species (Burckhardt \& Queiroz 2020). As with related aphids, scale insects and whiteflies, psyllids feed exclusively on plant sap but, unlike these, are generally highly specialised with respect to the plant taxa on which they develop (Hollis 2004; Ouvrard 2020). Host plants belong mostly to the eudicots (e.g., Fabaceae Juss., Myrtaceae Juss. and Sapindales Juss. ex Bercht. \& J.Presl) and, to a lesser extent, to the Magnoliales Bromhead; only a few species are associated with monocots and conifers (Ouvrard et al. 2015). Psyllids occur in all biogeographical regions of the world except for Antarctica. Their greatest diversity is in the tropics and south temperate regions (Hollis 2004). The Afrotropical and Neotropical biogeographical realms are probably particularly species-rich but also constitute the least known faunas (Burckhardt \& Queiroz 2020).

Classifications are efficient tools for organising and communicating biodiversity data especially when they are composed of rigorously tested monophyletic taxa. For a long time, psyllid classifications were dominated by studies of the adult morphology of north temperate taxa lacking well-defined analytical methods which resulted in highly artificial classifications (e.g., Bekker-Migdisova 1973). Several revisions of tropical and south temperate taxa and the study of immatures using phenetic and cladistic methodology culminated in the seminal paper of White \& Hodkinson (1985) who proposed a classification comprising eight families. This paper also summarises the history of psyllid systematics. White \& Hodkinson's (1985) paper triggered a series of mostly morphological studies testing their groupings. The results of these revisions were summarised in the revised classification by Burckhardt \& Ouvrard (2012).

Recently, the results of comprehensive molecular phylogenetic analyses of Psylloidea were published (Percy et al. 2018) based on around 400 of the 4000 described species. A subsequent study comprising 56 species focused on east Palaearctic/Oriental taxa (Cho et al. 2019). While these analyses confirmed many of the previously recognised taxa (at family, subfamily or genus level), there are some notable differences with respect to the most recent classification by Burckhardt \& Ouvrard (2012), and in some instances the molecular data resolved taxa which were previously recognised as polyphyletic.

Here, we present a revised classification addressing the family group levels. We assign all genus group names to the appropriate family, subfamily, tribe or subtribe. We also redefine a few genera in cases where this helps to understand the family level classification and reflect systematic information supported by the molecular data.

\section{Material and methods}

The scope of the classification proposed here follows that by Burckhardt \& Ouvrard (2012), i.e., it includes all published family and genus-group names of extant and fossil taxa of true Psylloidea (Ouvrard et al. 2010). The mesozoic family Liadopsyllidae Martynov, 1926, which is considered the stem-group (Burckhardt \& Poinar 2019) or sister-group (Drohojowska et al. 2020) of true Psylloidea, is not considered here.

The genera are organised alphabetically according to family and, where present, subfamily and tribe. No attempt is made to list all citations and ranks of family-group names published in the literature. Moreover, misspellings are not listed systematically either. This information can be found in Psyl'list (Ouvrard 2020). Synonyms, including new ones, of family-group names are listed under the respective valid name. For each valid family, subfamily or tribe, differences to the concept of Burckhardt \& Ouvrard (2012) are discussed and new taxa are diagnosed with a formal description to satisfy the provisions of International Commission on Zoological Nomenclature (1999, 2012; thereafter ICZN 1999/2012). All valid genus-group names are listed with author and year. Synonyms, including new ones, are listed in parentheses after the valid genus name without authors or dates. More information is available on the 
Psyl'list website (Ouvrard 2020). The data of specimen illustrated on Figs 2-3, 5-8 is provided in the Suppl. file 1.

This revised classification reflects, as well as possible, the phylogenies presented by Percy et al. (2018) and Cho et al. (2019). The taxa (families, subfamilies, tribes, subtribes or genera) included in these molecular analyses are marked with an asterisk. Those taxa not included in the molecular analyses are attributed to higher taxa following Burckhardt \& Ouvrard's (2012) classification or, if new morphological evidence is available, placed with diagnostic characters given. The phylogenies by Percy et al. (2018) and Cho et al. (2019) are largely congruent. Significant differences between the two studies are discussed under the relevant taxa. In a few cases with contradictory evidence between analyses, we took an arbitrary decision, to choose the grouping that needed the least changes, i.e., the one that was closest to the classification of Burckhardt \& Ouvrard (2012), or that was supported by the phylogenies by Percy et al. (2018) in favour of those by Cho et al. (2019) as the former was based on a more comprehensive sampling of taxa.

Representatives of almost all described psyllid genera and large amounts of undescribed material, including new genera, were examined mostly from the following institutions: Natural History Museum, London (BMNH); Naturhistorisches Museum, Basel (NHMB); Muséum d'histoire naturelle, Genève (MHNG); National Museum of Natural History, Washington, DC. Additional material was also examined from the Zoological Institute of the Russian Academy of Sciences, St. Petersburg; the Agricultural University, Beijing; the Australian National Insect Collection, Canberra; the New Zealand Arthropod Collection, Auckland; the Muséum national d'histoire naturelle, Paris; the Moravian Museum, Brno and the Museum für Naturkunde, Berlin.

\section{Results}

\section{Taxonomy}

Class Insecta Linnaeus, 1758

Order Hemiptera Linnaeus, 1758

Suborder Sternorrhyncha Duméril, 1806

Superfamily Psylloidea Latreille, 1807

Percy et al. (2018) presented two mitogenome (mtg) phylogenies that we refer to here as the AN tree ('allnucleotide' tree) and the CC tree ('conserved-codon' tree), as well as a much reduced taxon sampling using a nuclear genome analysis, and a combined mitochondrial and nuclear data analysis. Due to the greater taxon sampling for the mitogenome analyses, we refer mostly to these results here. The results of Cho et al. (2019) are similar to the AN tree. In the main, analyses in Percy et al. (2018) and Cho et al. (2019) had considerable congruence, with notable exceptions discussed below. Both mtg trees are similar and recover the same crown groups. The major difference lies in the basal groupings. The Aphalaridae Löw, 1879, as defined here, is a paraphyletic basal assemblage in the AN tree (also paraphyletic in Cho et al. 2019) and a poorly supported monophylum in the CC tree. Carsidaridae Crawford, 1911 (including Pachypsylla) and Homotomidae Heslop-Harrison, 1958 form a poorly supported sister group in the AN tree and a paraphyletic, basal assemblage in the CC tree. The former hypothesis (i.e., sister family relationship between Carsidaridae (without Pachypsyllinae Crawford, 1914) and Homotomidae) is supported by two putative morphological synapomorphies (Hollis \& Broomfield 1989) and is recovered with stronger support in the nuclear genome data in Percy et al. (2018) as well as combined data in Cho et al. (2019). In both mtg trees, the Mastigimatinae Bekker-Migdisova, 1973 constitutes the sister group to a well supported (94\%) clade comprising the Liviidae Löw, 1879, as defined here, and the PTCD clade (Psyllidae, Triozidae Löw, 1879, Calophyinae Vondráček, 1957 sensu Burckhardt \& 
Ouvrard (2012), Diaphorina Löw,1880 and Katacephala Crawford, 1914). This grouping differs from that of Burckhardt \& Ouvrard (2012) who included Mastigimatinae in their artificial Calophyidae. For this reason, Mastigimatinae is removed from Calophyidae and given family rank here. This move is supported by Cho et al. (2019) although the phylogenetic placement of Mastigimatinae is not identical. The Liviidae, as defined here, is a poorly supported monophylum in the AN tree and paraphyletic in the $\mathrm{CC}$ tree. It is also recovered as paraphyletic in combined data analyses in both Percy et al. (2018) and Cho et al. (2019). In both mtg trees, the PTCD clade is very strongly supported (100\%) (consistent with Cho et al. 2019), and Calophyidae Vondráček, 1957 (without Mastigimatinae) constitutes the sister taxon of the remainder of taxa in the PTCD clade with good (AN tree) or poor support (CC tree); notably, an alternative placement of Calophyidae as sister to Triozidae (albeit with mixed support) in combined data analyses in both Percy et al. (2018) and Cho et al. (2019) serves to emphasise that phylogenetic placement within the PTCD clade awaits robust confirmation. The support of the monophyly of Psyllidae (including Diaphorina and Katacephala) is good (AN tree) or poor (CC tree) and that of Triozidae very strong in both trees (99\%). Again, due to ambiguity in the placement of Diaphorina in the combined data analysis in Percy et al. (2018), additional analyses will be required for robust confirmation. In summary, not all taxonomic groups recognized here are strongly supported as monophyla in all or any of the molecular analyses, in some cases we have erred on the side of providing a practical and stable classification, particularly where ambiguity in molecular analyses remains. A summary of family interrelationships adopted here is shown in Fig. 1.

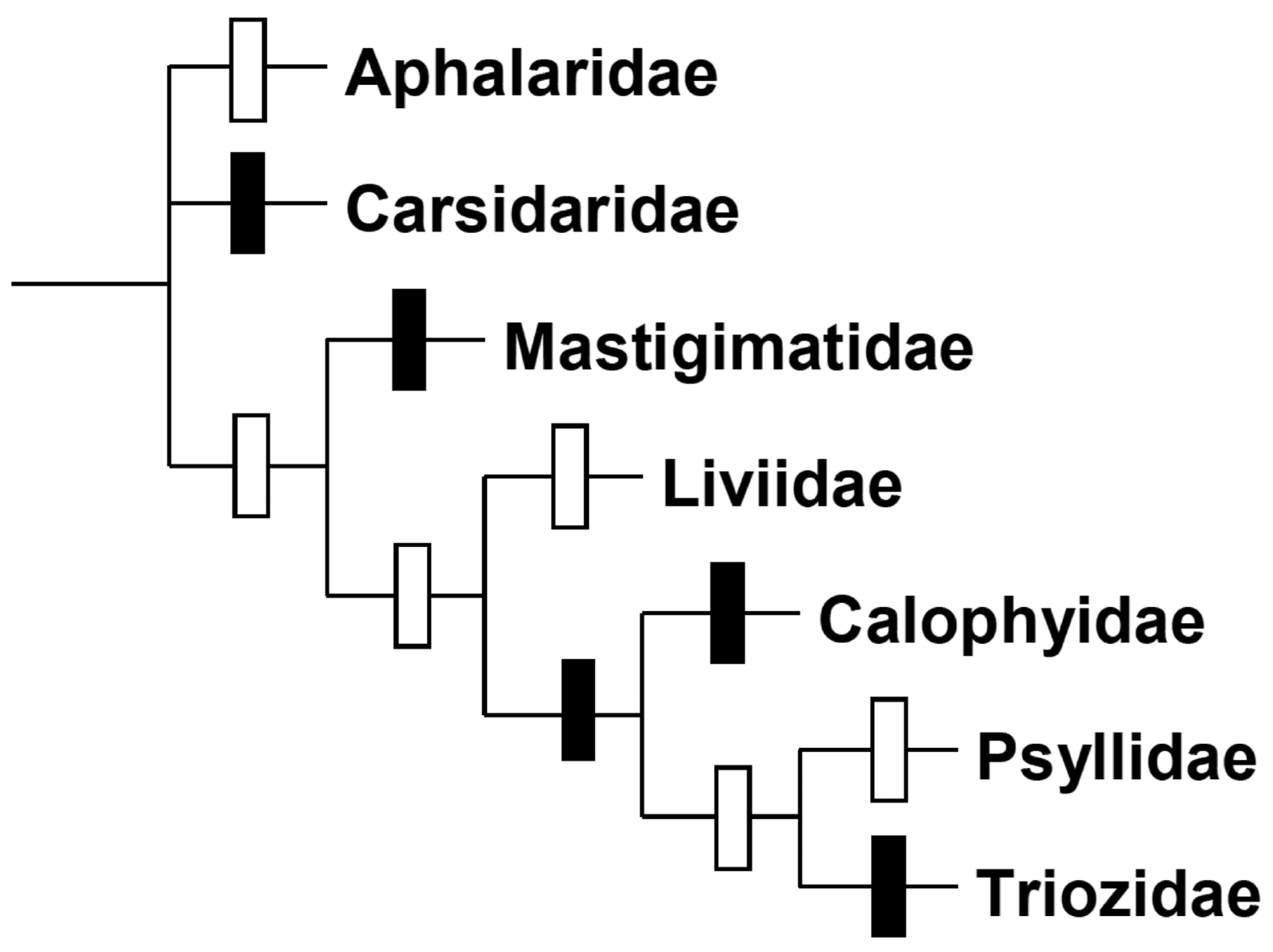

Fig. 1. Cladogram representation of the classification of Psylloidea Latreille, 1807 adopted here, node symbols indicate families with poor to moderate support (white), or strong support (black) in molecular analyses (Percy et al. 2018). 
BURCKHARDT D. et al., Updated classification of the jumping plant-lice

Family *Aphalaridae Löw, 1879

\section{Comments}

In both mtg trees, Aphalaridae contains six strongly supported monophyla which we rank as subfamilies: Aphalarinae, Microphyllurinae subfam. nov., Phacopteroninae Heslop-Harrison, 1958 stat. nov., Rhinocolinae Vondráček, 1957, Spondyliaspidinae Schwarz, 1898 and a clade of seven undescribed species from New Caledonia representing an unnamed genus and subfamily. This last subfamily is not further treated here and will be described in another paper (Percy, unpublished). There is evidence (from multiple molecular analyses) that these six subfamilies are likely not collectively monophyletic, however, there is still insufficient data to clarify the phylogenetic placement of each monophyletic subfamily with respect to the others, and therefore, rather than recognize each as a separate family, we have retained them as subfamilies within Aphalaridae "sensu lato" pending further analyses. In Aphalaridae, we also place Togepsyllinae Bekker-Migdisova, 1973 and Cecidopsyllinae Li, 2011 stat. nov. which were not included in the molecular analyses by Percy et al. (2018) but representatives were analysed by Cho et al. (2019). A morphological character shared by all constituent subfamilies, and putative synapomorphy for the family, is the tarsal arolium of the immatures which is either completely absent or forms a lobe lacking an unguitractor (Burckhardt \& Ouvrard 2012).

Apart from strong support of the sister group relationship of Microphyllurinae subfam. nov. (as "Parapaurocephala" in Percy et al. 2018) and Phacopteroninae stat. nov., there are no consistent and well-supported relationships between the subfamilies in the molecular analyses by Percy et al. (2018). A putative morphological synapomorphy grouping the Rhinocolinae, Spondyliaspidinae and Togepsyllinae is the tubercular or knob-like meracanthus rather than horn-shaped as in the other aphalarid subfamilies and most other Psylloidea. Luo et al. (2017) listed some putative synapomorphies suggesting a close relationship of Rhinocolinae and Togepsyllinae, a relationship which was also shown in Drohojowska's (2015) trees based on an analysis of the thorax morphology, and recovered in the molecular data set of Cho et al. (2019).

Aphalaridae, in the present definition, differs from that of Burckhardt \& Ouvrard (2012) in the positions of Cecidopsyllinae, Microphyllurinae subfam. nov., Pachypsyllinae and Phacopteroninae. Cecidopsylla Kieffer, 1905, was assigned to Calophyidae (Mastigimatinae) and is transferred here to Aphalaridae (Cecidopsyllinae). Microphyllurus Li, 2002, the only member of Microphyllurinae subfam. nov., was treated as a junior synonym of Peripsyllopsis Enderlein, 1926 (Liviidae: Euphyllurinae: Diaphorinini) by Burckhardt \& Ouvrard (2012), whereas the "Paurocephala' longicella group", which we consider here a synonym of Microphyllurus (see below), was referred to Aphalaridae (Rhinocolinae). Pachypsyllinae was part of Aphalaridae and is transferred here to Carsidaridae. Phacopteroninae was considered a family of basal position within Psylloidea, and a basal position for Phacopteronidae as sister to the remaining Psylloidea was strongly supported in Cho et al. (2019); this is one of the notable differences with analyses in Percy et al. (2018). It may be that the different taxon sampling strategies were critical in determining these results, but here we have elected to adopt the placement using the more comprehensive taxon sampling in Percy et al. (2018).

Subfamily *Aphalarinae Löw, 1879

\section{Comments}

The Aphalarinae is strongly supported as a monophylum in molecular analyses (Percy et al. 2018; Cho et al. 2019), morphologically (Loginova 1964; Brown \& Hodkinson 1988; Burckhardt \& Queiroz 2013; Ouvrard et al. 2013) and by the pattern of sperm formation (Labina et al. 2014). The subfamily includes two monophyletic tribes: the extant Aphalarini and the extinct Paleopsylloidini†. 
Tribe *Aphalarini Löw, 1879

Caillardiini Loginova, 1964: 447.

Coelocarinae Li, 2011: 351.

Colposceniini Bekker-Migdisova, 1973: 109.

Eumetoecini Li, 2011: 356.

Gyropsyllini White \& Hodkinson, 1985: 270.

Stigmaphalarini Vondráček, 1957: 140, nomen nudum, no included genera, recognised by Loginova (1974).

Xenaphalarini Loginova, 1964: 447.

\section{Comments}

Aphalarini comprises the extant members of the subfamily and is probably monophyletic. It has been diagnosed by Loginova (1964), Brown \& Hodkinson (1988) and Burckhardt \& Queiroz (2013). The phylogenetic relationships between the 16 recognised genera were analysed by Burckhardt \& Queiroz (2013). In the molecular analyses of Percy et al. (2018) six of the genera were included. The molecular analyses share with the morphological tree by Burckhardt \& Queiroz (2013) the basal position of Colposcenia and the sister group relationship of Aphalara and Craspedolepta (the latter was recovered also by Cho et al. 2019).

\section{Included genera}

*Aphalara Foerster, 1848 (syn. Pseudaphorma, Rumicita); Brachystetha Loginova, 1964; Caillardia de Bergevin, 1931; *Colposcenia Enderlein, 1929 (syn. Phanerostigma, Stigmaphalara); *Craspedolepta Enderlein, 1921 (syn. Anomocera, Cerna, Loginovia, Magnaphalara, Neocraspedolepta, Paracraspedolepta, Tetrafollicula, Xanioptera); Crastina Loginova, 1964 (syn. Eustigmatia); Epheloscyta Loginova, 1976; Eumetoecus Loginova, 1961; Eurotica Loginova, 1962; Gyropsylla Brèthes, 1921 (syn. Metaphalara, Coelocara sensu Li nec Tuthill); Hodkinsonia Burckhardt et al., 2004 (replacement name for Burckhardtia Brown \& Hodkinson nec Frech); *Lanthanaphalara Tuthill, 1959; *Limataphalara Hodkinson, 1992; *Neaphalara Brown \& Hodkinson, 1988; Rhodochlanis Loginova, 1964 (syn. Rhombaphalara); Xenaphalara Loginova, 1961.

\section{Tribe Paleopsylloidini† Bekker-Migdisova, 1985}

Palaeoaphalarinae† Klimaszewski in Klimaszewski \& Popov, 1993: 14.

\section{Comments}

The poorly defined Paleopsylloidini† comprises seven Eocene genera. Ouvrard et al. (2013) suggested that the tribe may be paraphyletic with respect to Aphalarini which includes only recent representatives.

In an overview of Hemiptera represented in the Insect Limestone (latest Eocene) of the Isle of Wight, UK, Szwedo et al. (2019) listed the tribes Aphalarini and Palaeoaphalarini†. They placed Paleopsylloides $\dagger$ Bekker-Migdisova, 1985, type genus of Palaeoaphalarinit, in the former tribe rather than in the latter, which is an obvious oversight.

\section{Included genera}

Carsidarina† Bekker-Migdisova, 1985 (syn. Palaeoaphalara $\uparrow$ ); Catopsylla† Scudder, 1890 (syn. Psyllites $\dagger$ ); Eogyropsylla† Klimaszewski, 1993 (syn. Parascenia $\dagger$ ); Lapidopsylla† Klimaszewski in Klimaszewski and Popov, 1993; Necropsylla† Scudder, 1890; Paleopsylloides $\dagger$ Bekker-Migdisova, 1985; Proeurotica† Bekker-Migdisova, 1985 (syn. Plesioaphalara $\dagger$ ). 
Subfamily Cecidopsyllinae Li, 2011 stat. rev. et nov.

\section{Comments}

The monotypic Cecidopsyllinae was diagnosed by Li (2011); for diagnoses of Cecidopsylla see also Burckhardt (1991b) and Yang et al. (2009). In the study of Cho et al. (2019), Cecidopsylla forms the sister taxon to all other psyllids, except for Pseudophacopteron (Phacopteroninae). For this reason, we transfer it to Aphalaridae and remove Cecidopsyllinae from synonymy with Mastigimatinae (Burckhardt \& Ouvrard 2012). Within the Mastigimatinae as defined by Burckhardt et al. (2018b), Cecidopsylla resembles Synpsylla in the shape of the head, antennae and forewings but there are no detailed synapomorphies suggesting that the two are phylogenetically close. Awaiting new evidence, we leave the latter in the Mastigimatidae (see discussion there).

\section{Included genus}

Cecidopsylla Kieffer, 1905.

Subfamily *Microphyllurinae subfam. nov. urn:1sid:zoobank.org:act:74D16A9C-63DA-4190-9BC0-E0BC80904B17

Fig. 2

\section{Type genus}

Microphyllurus Li, 2002.

\section{Diagnosis}

Adult

Head with subtrapezoidal vertex smoothly passing into genae that lack processes. Frons triangular. Antenna about as long as head width. Clypeus flattened, triangular. Propleurites with subequal epimeron and episternum. Tibiae distinctly longer than femora; metacoxa with small pointed meracanthus and small membranous lobe on metatrochanteral cavity; metatibia without genual spine, bearing an open crown of 8-9 densely spaced, sclerotised, apical spurs; metabasitarsus with 2 spurs. Forewing weakly coriaceous, covered in surface spinules; costal break and pterostigma developed; veins $\mathrm{R}$ and $\mathrm{M}+\mathrm{Cu}$ subequal, branches of vein $\mathrm{M}$, and vein $\mathrm{Cu}_{1 \mathrm{a}}$ very long; anal break close to apex of vein $\mathrm{Cu}_{1 \mathrm{~b}}$. Hindwing with costal setae not grouped; vein $\mathrm{R}+\mathrm{M}$ developed. Male proctiger one-segmented; in profile, with large posterior lobe in basal half. Female terminalia cuneate.

\section{Description}

\section{Adult}

Head, in profile, inclined at $45^{\circ}$ from longitudinal body axis (Fig. 2A). Vertex subtrapezoidal, passing smoothly into genae which are not produced into processes; coronal suture fully developed (Fig. 2C); frons triangular with median ocellus situated at dorso-median edge (Fig. 2D). Antenna 10-segmented, filiform, about as long as head width. Clypeus flattened, triangular (Fig. 2D), not visible in profile. Rostrum very short, hardly exceeding procoxae. Thorax moderately arched dorsally; pronotum transversely ribbon-shaped, longer medially than laterally; mesopraescutum in longitudinal body axis shorter than mesoscutum which is strongly bulged; propleurites with subequal epimeron and episternum. Legs (Fig. 2B) moderately slender, tibiae distinctly longer than femora; metacoxa with small pointed meracanthus and small membranous lobe on metatrochanteral cavity (Fig. 2B: lobe); metatibia without genual spine, bearing an open crown of 8-9 densely spaced, sclerotised, apical spurs; metabasitarsus with 2 spurs (Fig. 2B). Forewing weakly coriaceous, membrane semitransparent, covered in surface spinules; costal break and pterostigma developed; veins $\mathrm{R}$ and $\mathrm{M}+\mathrm{Cu}$ subequal, branches of vein $\mathrm{M}$, and vein $\mathrm{Cu}_{1 \mathrm{a}}$ very long; anal break close to apex of vein $\mathrm{Cu}_{1 \mathrm{~b}}$. Hindwing slightly shorter than forewing, membranous; costal setae not grouped; vein $\mathrm{R}+\mathrm{M}$ developed. Male proctiger one-segmented; in profile, with large 
posterior lobe in basal half. Male subgenital plate semiglobular. Paramere shorter than proctiger. Female terminalia cuneate. Circumanal ring oval.

\section{Immature}

Unknown.

\section{Comments}

In describing Paurocephala longicella Tuthill (1943a) noted that the forewing venation differs from other known species of Paurocephala Crawford, 1913. In a review of Rhinocola Foerster, 1848 and associated genera, Heslop-Harrison (1952) discussed P. longicella for which he erected 'Parapaurocephala' but failed to provide a description. The name is, therefore, a nomen nudum and not available (ICZN 1999/2012: article 13.1.1). Burckhardt \& Basset (2000) referred to the taxon as "Paurocephala' longicella group". Based on a single male, Li (2002) described Microphyllurus longicellus Li, 2002, from Hainan (China). We have examined the holotype of Microphyllurus longicellus (DB, 31 Aug. 2009) and material identified as Paurocephala longicella from Fiji and Samoa (MHNG, 9 Jul. 2018). We conclude that the samples are congeneric but represent different species, one each in China, Fiji and Samoa, respectively, and suggest the following nomenclatorial acts:

Microphyllurus Li, 2002, stat. rev., removed from synonymy with Peripsyllopsis.

Microphyllurus longicellus (Tuthill, 1943) comb. nov. from Paurocephala.

Microphyllurus lii nom. nov. for Microphyllurus longicellus Li, 2002, nec Tuthill (1943a).

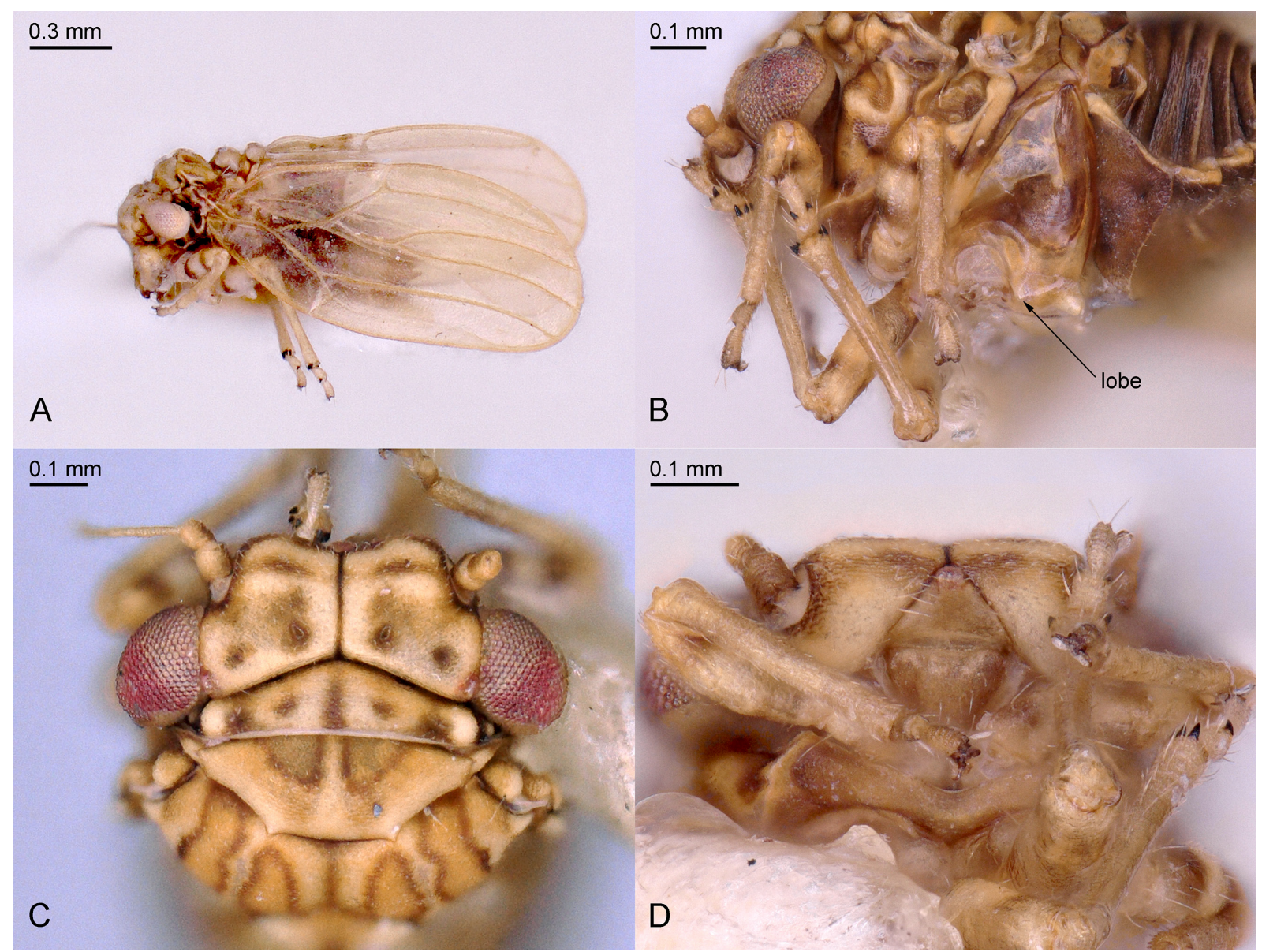

Fig. 2. Microphyllurinae subfam. nov.: Microphyllurus sp. A. Habitus, in profile view. B. Legs. C. Head, dorsal view. D. Head, ventral view. 


\section{Included genus}

*Microphyllurus Li, 2002 (syn. Microphyllura, misspelling, Li, 2011; Parapaurocephala HeslopHarrison, nomen nudum; 'Paurocephala' longicella group sensu Burckhardt \& Basset, 2000).

Subfamily *Phacopteroninae Heslop-Harrison, 1958 stat. nov.

Phacoseminae Kieffer, 1906: 387 (the substitute name Phacopteronidae is maintained according to the ICZN 1999/2012, article 40.2).

Pseudophacopterini Bekker-Migdisova, 1973: 103.

Pseudophacopteroninae Li, 2011: 233.

\section{Comments}

The Phacopteroninae is strongly supported as a monophylum in both mtg trees and morphologically (Heslop-Harrison 1958; White \& Hodkinson 1985). The subfamily corresponds to the concept of Burckhardt \& Ouvrard (2012). The genera are poorly defined and their phylogenetic relationships are unknown.

\section{Included genera}

*Cornegenapsylla Yang \& Li, 1982 (syn. Neophacopteron); Phacopteron Buckton, 1896 (syn. Phacosema); Phacosemoides Costa Lima \& Guitton, 1962; *Pseudophacopteron Enderlein, 1921 (syn. Chineura); Sulciana† Klimaszewski, 1998.

\section{Subfamily *Rhinocolinae Vondráček, 1957}

Anomalopsyllinae Vondráček, 1963: 263.

Apsyllini Bekker-Migdisova, 1973: 107.

\section{Comments}

The Rhinocolinae is strongly supported as a monophylum in both $\mathrm{mtg}$ trees, morphologically (Burckhardt \& Lauterer 1989; Burckhardt \& Basset 2000; Burckhardt \& Queiroz 2017) and, to a certain extent, by the pattern of sperm formation (Labina et al. 2014). It corresponds to the concept of Burckhardt \& Ouvrard (2012). The phylogenetic relationships within the subfamily have been analysed by Burckhardt \& Lauterer (1989), Burckhardt \& Basset (2000), and Ouvrard et al. (2010).

\section{Included genera}

Agonoscena Enderlein, 1914; Ameroscena Burckhardt \& Lauterer, 1989; Anomalopsylla Tuthill, 1952; * Apsylla Crawford, 1912; Cerationotum Burckhardt \& Lauterer, 1989; Crucianus Burckhardt \& Lauterer, 1989; Leurolophus Tuthill, 1942; Lisronia Loginova, 1976 (syn. Pseudotingidiforma HeslopHarrison, 1952 nomen nudum [no type designated] syn. nov., Rhachistoneura); Megagonoscena Burckhardt \& Lauterer, 1989; Moraniella Loginova, 1972; Notophyllura Hodkinson, 1986; Protoscena $\dagger$ Klimaszewski, 1997; *Rhinocola Foerster, 1848; Rhusaphalara Park \& Lee, 1982 (syn. Koreaphalara); Tainarys Brèthes, 1920 (syn. Vicinilura†).

\section{Subfamily *Spondyliaspidinae Schwarz, 1898}

Livillinae Scott, 1882: 462, unavailable, stem genus not included.

\section{Comments}

The Spondyliaspidinae is strongly supported as a monophylum in both mtg trees, morphologically (Burckhardt 1991a) and by the pattern of sperm formation (Labina et al. 2014). The concept of the 
subfamily is the same as that by Burckhardt \& Ouvrard (2012). In the mtg analyses there is a wellsupported basal split between Ctenarytaina Ferris \& Klyver, 1932 and the remainder of the subfamily (Anoeconeossa Taylor, 1987, Australopsylla Tuthill \& Taylor, 1955, Blastopsylla Taylor, 1985, Boreioglycaspis Moore, 1964, Cardiaspina Crawford, 1911, Creiis Scott, 1882, Cryptoneossa Taylor, 1990, Glycaspis Taylor, 1960, Lasiopsylla Froggatt, 1900 and Platyobria Taylor, 1987).

Tribe *Ctenarytainini White \& Hodkinson, 1985, stat. rev., sensu novo

\section{Comments}

Burckhardt (1991a) suggested that the tribe Ctenarytainini sensu White \& Hodkinson (1985) and Taylor (1990) is probably not monophyletic. The mtg analyses confirm this. Here we define the tribe in a new sense by the presence in the adult of a longitudinal comb of bristles on the mesotibia and a knob-like meracanthus, the latter character probably being a symplesiomorphy.

\section{Included genera}

*Ctenarytaina Ferris \& Klyver, 1932 (syn. Bosellius, Eurhinocola, Euryopsylla, Loginoviana Mathur nomen nudum, Papiana); Syncarpiolyma Froggatt, 1901.

\section{Tribe *Spondyliaspidini Schwarz, 1898}

\section{Comments}

The mtg analyses strongly support the monophyly of a group of ten genera which lack, in the adult, a longitudinal comb of bristles on the mesotibia and a proper meracanthus. The latter character probably constitutes a synapomorphy. Within the tribe there is a strong support for a clade embracing Australopsylla, Cardiaspina, Creiis, Glycaspis and Lasiopsylla and the sister group relationship of Anoeconeossa and Cryptoneossa. The sister group relationship of Creiis and Lasiopsylla (as currently defined) is only weakly supported with Creiis paraphyletic with respect to Lasiopsylla. The two genera differ morphologically only in the shape of the forewing. There are another 11 genera which are not included in the molecular analyses.

\section{Included genera}

Agelaeopsylla Taylor, 1990; *Anoeconeossa Taylor, 1987; *Australopsylla Tuthill \& Taylor, 1955; *Blastopsylla Taylor, 1985; Blepharocosta Taylor, 1992; *Boreioglycaspis Moore, 1964; *Cardiaspina Crawford, 1911 (replacement name for Cardiaspis Schwarz nec Amyot, nec Saunders, syn. Pennapsylla Froggatt nomen nudum); *Creiis Scott, 1882; *Cryptoneossa Taylor, 1990; Dasypsylla Froggatt, 1900 (syn. Callistochermes); Eriopsylla Froggatt, 1901; Eucalyptolyma Froggatt, 1901; *Glycaspis Taylor, 1960; Hyalinaspis Taylor, 1960; Kenmooreana Taylor, 1984; *Lasiopsylla Froggatt, 1900 (syn. Uhleria); Leptospermonastes Taylor, 1987; Phellopsylla Taylor, 1960 (replacement name for Thea Scott nec Mulsant); Phyllolyma Scott, 1882 (syn. Cometopsylla); *Platyobria Taylor, 1987; Spondyliaspis Signoret, 1879 (syn. Scenitopsylla, Spondytora).

\section{Subfamily Togepsyllinae Bekker-Migdisova, 1973}

Hemipteripsyllinae Yang \& Li, 1981: 186.

\section{Comments}

This small, probably monophyletic subfamily comprising two highly modified genera in South and East Asia as well as in the Neotropics (Brown \& Hodkinson 1988; Hodkinson 1990; Luo et al. 2017) 
was not included in the molecular study of Percy et al. (2018). Its assignement to the Aphalaridae by Burckhardt \& Ouvrard (2012) is supported by the molecular study of Cho et al. (2019).

\section{Included genera}

Syncoptozus Enderlein, 1918; Togepsylla Kuwayama, 1931 (syn. Hemipteripsylla, Tingidiforma HeslopHarrison nomen nudum).

Family *Calophyidae Vondráček, 1957

\section{Comments}

Burckhardt \& Ouvrard (2012) admitted the artificial nature of their Calophyidae comprising five subfamilies. Two of these, Calophyinae and Mastigimatinae were included in the molecular analyses of Percy et al. (2018) and Cho et al. (2019), which both confirmed nonmonophyly of Calophyidae. The Mastigimatinae is removed here from Calophyidae and raised to family status. The other four subfamilies lack all metabasitarsal spurs. In addition, Atmetocraniinae Becker-Migdisova, 1973, Calophyinae and Metapsyllinae Kwon, 1983 bear an internal comb of apical metatibial spurs suggesting they may be closely related. Atmetocraniinae and Calophyinae share also the one-segmented asymmetric antennal flagellum in immatures (Burckhardt \& Mifsud 2003; Burckhardt \& Ouvrard 2012). With this, admittedly weak, evidence we keep the four subfamilies in the Calophyidae awaiting evidence to the contrary.

Subfamily Atmetocraniinae Becker-Migdisova, 1973

\section{Comments}

The subfamily was diagnosed by Burckhardt \& Ouvrard (2012).

\section{Included genus}

Atmetocranium Tuthill, 1952.

Subfamily *Calophyinae Vondráček, 1957

Microceropsyllini Bekker-Migdisova, 1973: 104.

Strogylocephalidae Li, 2011: 1257.

\section{Comments}

The subfamily was diagnosed by Burckhardt \& Ouvrard (2012).

\section{Included genera}

*Calophya Löw, 1879 (syn. Calophya (Neocalophya), Holotrioza, Microceropsylla, Paracalophya, Pelmatobrachia); Pseudoglycaspis Brown \& Hodkinson, 1988; *Strogylocephala Crawford, 1917 (syn. Synaphalara).

Subfamily Metapsyllinae Kwon, 1983

\section{Comments}

The subfamily was diagnosed by Burckhardt \& Ouvrard (2012).

\section{Included genus}

Metapsylla Kuwayama, 1908. 
Subfamily Symphorosinae Li, 2002

\section{Comments}

The subfamily was diagnosed by $\mathrm{Li}$ (2002). Burckhardt \& Ouvrard (2012) pointed out the similarity of the male subgenital plate of Symphorosus and Cecidopsylla (classified here in Aphalaridae: Cecidopsyllinae) but did not list detailed synapomorphies between the two genera.

\section{Included genus}

Symphorosus Li, 2002.

Family *Carsidaridae Crawford, 1911, sensu novo

\section{Comments}

In both mtg trees the monophyly of Carsidaridae and Pachypsylla is strongly or very strongly supported. Carsidaridae + Pachypsylla (Pachypsyllinae) and Homotomidae form a poorly supported sister group in the AN tree and both families are included in an unresolved basal assemblage in the CC tree. In the molecular analyses by Cho et al. (2019), Celtisaspis (Pachypsyllinae) is recovered as weakly supported sister-group of Homotomidae, rather than Carsidaridae, and the monophyly of Carsidaridae, Celtisaspis and Homotomidae is well supported. Hollis \& Broomfield (1989) listed two putative morphological synapomorphies to link Carsidaridae and Homotomidae: 1) the presence of a pair of large tubercles on the metapostnotum, and 2) all three ventral sense organs of the metafemur in a basal position. These characters are present also in Pachypsyllinae, though the tubercles on the metapostnotum are relatively small in Celtisaspis. Cho et al. (2019) mention the bipartite male proctiger as a putative synapomorphy of Homotomidae+Pachypsyllinae. As in Aphalaridae, the three taxa discussed here form, depending on the type of analysis, an unresolved basal (paraphyletic) assemblage or a monophylum with contradicting relationships between the constituent groups. For reasons of consistency, we include the three groups in the single family Carsidaridae. The concept of Carsidaridae by Burckhardt \& Ouvrard (2012) is broadened here to include also Homotomidae and Pachypsyllinae which is transferred from Aphalaridae.

\section{Subfamily *Carsidarinae Crawford, 1911}

Prionocnemidae Scott, 1882: 466, invalid as not derived from an included genus name.

Tenaphalarini Heslop-Harrison, 1958: 577-578.

Mesohomotomini Bekker-Migdisova, 1973: 101.

\section{Comments}

In both mtg trees the monophyly of the subfamily is very strongly supported. Hollis (1987) provided a morphological diagnosis and analysed the intra-subfamily relationships. In the mtg analyses, with five of the eight recognised genera included, Mesohomotoma is in a moderately supported basal position, whereas in the morphological tree it is the sister taxon of Paracarsidara; and apart from a reasonably well supported clade comprising Protyora + Tenaphalara + Paracarsidara, the relationships between the other genera are only poorly supported.

\section{Included genera}

*Allocarsidara Hollis, 1987; Carsidara Walker, 1869 (syn. Eustigmia, Thysanogyna); Epicarsa Crawford, 1911; *Mesohomotoma Kuwayama, 1908 (syn. Udamostigma); *Paracarsidara HeslopHarrison, 1960; *Protyora Kieffer, 1906 (syn. Neocarsidara); *Tenaphalara Kuwayama, 1908; Tyora Walker, 1869 (syn. Carsidaroida, Nesiope). 
BURCKHARDT D. et al., Updated classification of the jumping plant-lice

Subfamily *Homotominae Heslop-Harrison, 1958, stat. rev.

\section{Comments}

The subfamily and its constituent tribes and subtribes were diagnosed by Hollis \& Broomfield (1989) (treated as family, subfamilies and tribes) who also analysed the generic relationships of the family using morphological evidence; the three subfamilies (here tribes) were represented in a trifurcation in their cladogram. The molecular analyses, in which only three genera were included, reflect this morphological tree but sampled only two subfamilies (here tribes). Following Ouvrard (2002), the classification of Burckhardt \& Ouvrard (2012) differs from that of Hollis \& Broomfield (1989) in the inclusion of Phytolyma Scott, 1882 in the Macrohomotominae White \& Hodkinson, 1985 (Phytolymini) rather than in the Aphalarinae. The classification presented here reflects that of Burckhardt \& Ouvrard (2012) though with reduced ranks.

Tribe Dynopsyllini Bekker-Migdisova, 1973, stat. rev.

Subtribe Diceraopsyllina Hollis \& Broomfield, 1989, stat. nov.

\section{Included genus}

Diceraopsylla Crawford, 1912.

Subtribe Dynopsyllina Bekker-Migdisova, 1973, stat. rev.

Triozamiini Bekker-Migdisova, 1973: 114.

\section{Included genera}

Afrodynopsylla Hollis \& Broomfield, 1989; Austrodynopsylla Hollis \& Broomfield, 1989; Dynopsylla Crawford, 1913 (syn. Crawfordella, Sphingocladia); Triozamia Vondráček, 1963.

Tribe *Homotomini Heslop-Harrison, 1958, stat. rev.

Subtribe *Homotomina Heslop-Harrison, 1958, stat. nov.

Psausiini Bekker-Migdisova, 1973: 102.

\section{Included genus}

*Homotoma Guérin-Méneville, 1844 (syn. Anisostropha, Austrohomotoma, Caenohomotoma, Harrisonella, Heterohomotoma, Labobrachia, Metapsausia, Psausia Enderlein, 1914, Psausia Yang \& $\mathrm{Li}, 1984)$.

Subtribe Synozina Bekker-Migdisova, 1973, stat. nov.

Synoziini White \& Hodkinson, 1985: 162 (misspelling).

\section{Included genus}

Synoza Enderlein, 1918. 
Tribe *Macrohomotomini White \& Hodkinson, 1985, stat. rev.

Subtribe *Edenina Bhanotar, Ghosh \& Ghosh, 1972, stat. nov.

\section{Included geneus}

*Mycopsylla Froggatt, 1901 (syn. Edenus).

Subtribe *Macrohomotomina White \& Hodkinson, 1985, stat. nov.

\section{Included genera}

*Macrohomotoma Kuwayama, 1908; Pseudoeriopsylla Newstead, 1911.

Subtribe Phytolymina White \& Hodkinson, 1985, stat. nov.

\section{Comments}

Differs from other subtribes in the Macrohomotomini in the presence of a costal break in the forewing and small tubercles on the metapostnotum (Burckhardt et al. 2018a). In Cho et al. (2019), Moriphila is nested in Homotoma.

\section{Included genera}

Moriphila Burckhardt \& Cho in Burckhardt et al., 2018a; Phytolyma Scott, 1882.

\section{Subfamily *Pachypsyllinae Crawford, 1914}

\section{Comments}

The subfamily was diagnosed by Tuthill (1943b) and White \& Hodkinson (1985).

\section{Included genera}

Celtisaspis Yang \& Li, 1982; *Pachypsylla Riley, 1885 (syn. Blastophysa); Tetragonocephala Crawford, 1914.

Family *Liviidae Löw, 1879

\section{Comments}

In both mtg trees, this poorly supported monophyletic or paraphyletic family contains two strongly supported monophyla and one monotypic taxon which we rank as subfamilies: Euphyllurinae, Liviinae and Neophyllurinae subfam. nov. There is no strong support for any particular sister group relationship, although in a backbone constraint analysis in Percy et al. (2018), Neophyllurinae subfam. nov. grouped more strongly with Liviinae than Euphyllurinae Crawford, 1914. The family as defined here differs from that of Burckhardt \& Ouvrard (2012) in that it lacks the Diaphorinini (minus Megadicrania and Psyllopsis, which are included here in the Euphyllurinae). Adults of Liviidae often have a crown of densely spaced apical spurs and immatures have multiple lanceolate or sectasetae.

\section{Subfamily *Euphyllurinae Crawford, 1914}

Psyllopsiini Vondráček, 1951: 128.

Pachypsylloidini Loginova, 1964: 457.

Strophingiinae White \& Hodkinson, 1985: 270. 


\section{Comments}

The Euphyllurinae as defined here is strongly supported as a monophylum in both mtg trees, morphologically it is, however, more difficult to diagnose. All species included here have immatures with a fan-shaped tarsal arolium bearing an unguitractor. Hosts are, as far as known, Ericaceae (Ericales), Oleaceae (Lamiales), Polygonaceae (Caryophyllales), Rutaceae and Sapindaceae (Sapindales), and Salvadoraceae (Brassicales). Its present concept, which is not further subdivided into tribes, embraces the constituents of the tribes Euphyllurini (except Neophyllura), Pachypsylloidini and Strophingiini of Burckhardt \& Ouvrard (2012), as well as Megadicrania, Peripsyllopsis and Psyllopsis (from Diaphorinini).

The molecular analyses clearly show that the Diaphorinini of Burckhardt \& Ouvrard (2012) is polyphyletic though only three of 13 genera were analysed. Of the 13 genera, only Megadicrania Loginova, 1976, Peripsyllopsis Enderlein, 1926 and Psyllopsis Löw, 1879, remain in Euphyllurinae. The other genera are transferred to Psyllidae: Caradocia, Epipsylla and Geijerolyma to Ciriacreminae, Diaphorina and Parapsylla to Diaphorininae, Katacephala, Lautereropsis, Notophorina and Tuthillia to Katacephalinae subfam. nov. and Cornopsylla to Psyllinae.

\section{Included genera}

Brachyphyllura Li, 2011; Crytophyllura Li, 2011; Eremopsylloides Loginova, 1964; *Euphyllura Foerster, 1848 (syn. Platystigma); Ligustrinia Loginova, 1973; Megadicrania Loginova, 1976; Pachypsylloides de Bergevin, 1927; Peripsyllopsis Enderlein, 1926; *Psyllopsis Löw, 1879; *Strophingia Enderlein, 1914; Shaerqia Kemal \& Koçak, 2009 (replacement name for Acaerus Loginova nec Pascoe; syn. Sureaca); Syringilla Loginova, 1967.

\section{Subfamily *Liviinae Löw, 1879}

Paurocephalini Vondráček, 1963: 277.

Diclidophlebiini Bekker-Migdisova, 1973: 100.

Camarotosceninae Li, 2011: 381.

Sinuonemopsyllinae Li, 2011: 373.

\section{Comments}

The monophyly of Liviinae is strongly supported in both $\mathrm{mtg}$ trees and also morphologically (Burckhardt \& Mifsud 2003). The concept of the subfamily is the same as that by Burckhardt \& Ouvrard (2012). Both morphologically and in the molecular analyses Diclidophlebia Crawford, 1920 and Paurocephala are closely related. Whereas each of the genera was recovered as monophyletic in a morphological study (Burckhardt \& Mifsud 2003), in the molecular analyses Diclidophlebia is paraphyletic with respect to Paurocephala.

\section{Included genera}

Aphorma Hodkinson, 1974 (syn. Leprostictopsylla); Camarotoscena Haupt, 1935; *Diclidophlebia Crawford, 1920 (replacement name for Heteroneura Crawford nec Fallén; syn. Aconopsylla, Gyroza, Haplaphalara, Paraphalaroida, Sinuonemopsylla, Woldaia); *Livia Latreille, 1802 (syn. Diraphia Illiger, Neolivia replacement name for Diraphia Waga nec Illiger, Vailakiella); *Paurocephala Crawford, 1913 (syn. Marpsylla, Paurocephala (Thoracocorna), Pauroterga); *Syntomoza Enderlein, 1921 (syn. Anomoterga, Homalocephala). 
Subfamily *Neophyllurinae subfam. nov.

urn:1sid:zoobank.org:act:2CB3C7BB-1F3C-4C9E-A8B0-F5AB5B6C537A

Fig. 3

\section{Type genus}

Neophyllura Loginova, 1973.

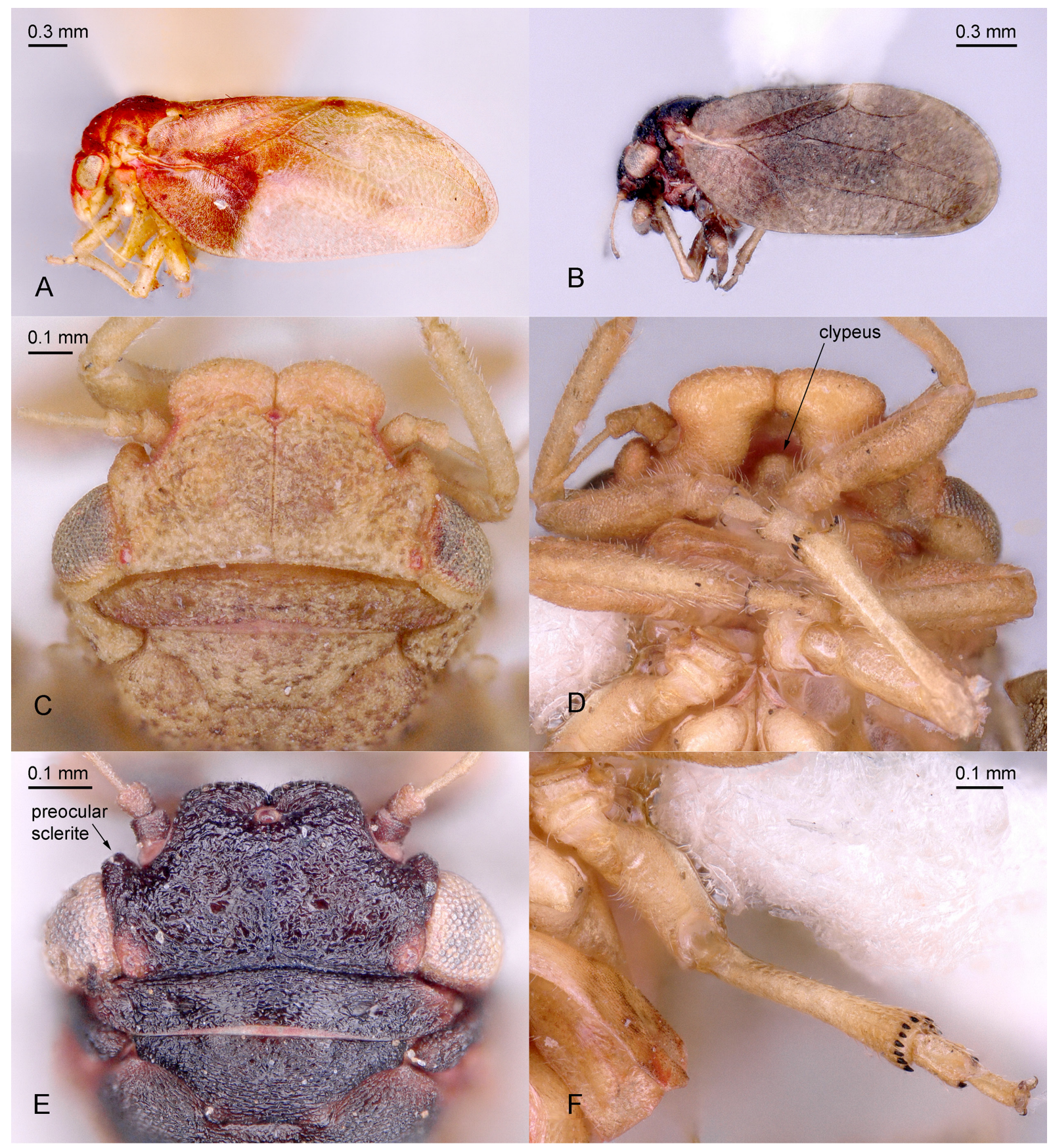

Fig. 3. Neophyllurinae subfam. nov.: Neophyllura spp. A. Neophyllura arbuticola (Crawford, 1914), habitus, in profile view. B. Neophyllura sp., habitus, in profile view. C-D, F. Neophyllura arctostaphyli (Schwarz, 1904). E. Neophyllura sp. C, E. Head, dorsal view. D. Head, ventral view. F. Hind leg. 


\section{Diagnosis}

\section{Adult}

Head with subtrapezoidal vertex that is separated from genae by incomplete transverse suture; genae forming transverse ridges; frons oval, almost completely covered by median ocellus; preocular sclerite developed, forming large tubercle. Thorax strongly arched dorsally; propleurites with subequal epimeron and episternum. Parapteron elongate, rectangular, much larger than tegula. Metacoxa with moderately large, blunt meracanthus and inconspicuous membranous tubercle on metatrochanteral cavity; metatibia without genual spine, bearing an open crown of 8-9 irregularly spaced, sclerotised, apical spurs; metabasitarsus with 2 spurs. Forewing membrane coriaceous, more or less rugose; costal break developed, pterostigma absent or indistinct; branches of vein M relatively long; anal break close to apex of vein $\mathrm{Cu}_{1 b}$.

\section{Fifth instar immature}

Caudal plate with additional pore fields.

\section{Description}

\section{Adult}

Head, in profile, strongly inclined at almost $90^{\circ}$ from longitudinal body axis (Fig. 3A-B). Vertex subtrapezoidal, separated from genae by incomplete transverse suture; genae forming transverse ridges; coronal suture fully developed; frons oval, almost completely covered by median ocellus; preocular sclerite developed, forming large tubercle (Fig. 3C, E). Antenna 10-segmented, filiform, about as long as head width. Clypeus pear-shaped, visible in profile (Fig. 3D). Rostrum very short, hardly exceeding procoxae. Thorax strongly arched dorsally; pronotum transversely ribbon-shaped (Fig. 3C, E); mesopraescutum in longitudinal body axis shorter than mesoscutum which is strongly bulged; propleurites with subequal epimeron and episternum. Parapteron elongate, rectangular, much larger than tegula. Legs relatively short, tibiae slightly longer than femora; basitarsi not much longer than broad; metacoxa with moderately large, blunt meracanthus and inconspicuous membranous tubercle on metatrochanteral cavity; metatibia without genual spine, bearing an open crown of 8-9 irregularly spaced, sclerotised, apical spurs; metabasitarsus with 2 spurs (Fig. 3F). Forewing oval or rhomboidal, membrane coriaceous, more or less rugose; costal break developed, pterostigma absent or indistinct; vein $\mathrm{R}$ shorter than $\mathrm{M}+\mathrm{Cu}$ or both veins subequal, branches of vein $\mathrm{M}$ relatively long; anal break close to apex of vein $\mathrm{Cu}_{1 b}$. Hindwing almost as long as forewing, membranous; costal setae grouped; vein $\mathrm{R}+\mathrm{M}$ developed. Male proctiger one-segmented; in profile, tubular. Male subgenital plate subglobular. Paramere lamellar. Female terminalia cuneate. Circumanal ring oval.

Fifth instar immature

Caudal plate bearing additional pore fields. Tarsal arolium short, fan-shaped with unguitractor.

\section{Included genus}

*Neophyllura Loginova, 1973 (syn. Arbutophila).

Family *Mastigimatidae Bekker-Migdisova, 1973, stat. nov.

Bharatianinae White \& Hodkinson, 1985: 272.

\section{Comments}

The taxon was diagnosed by Burckhardt \& Ouvrard (2012) and Burckhardt et al. (2018b). The former suggested the following sister group relationships: Bharatiana + Mastigimas and Cecidopsylla + Synpsylla, and Burckhardt et al. (2018b) indicated that Toonapsylla may be closely related to the former clade. Cho et al. (2019) showed that Cecidopsylla and Toonapsylla are not closely related and that the former has a basal position within Psylloidea. For this reason we transfer Cecidopsylla to Aphalaridae. Toonapsylla shares a series of morphological characters with Bharatiana+Mastigimas (Burckhardt et al. 2018b), 
supporting the monophyly of the three genera. Synpsylla resembles Cecidopsylla in the shape of the head, antennae and forewings but there are also important differences such as absence/presence of submedian ridges on the metapostnotum or number and arrangement of the apical metatibial spurs. Awaiting new evidence, we leave Synpsylla in the Mastigimatidae.

\section{Included genera}

Bharatiana Mathur, 1973; *Mastigimas Enderlein, 1921 (syn. Coelocara); Synpsylla Yang, 1984; Toonapsylla Burckhardt, 2018 in Burckhardt et al. (2018b).

Family *Psyllidae Latreille, 1807

\section{Comments}

The monophyly of Psyllidae is well (AN tree) or only moderately (CC tree) supported in the molecular analyses. The two mtg trees share the same internal topology with most clades strongly supported (Fig. 4). The composition of Psyllidae proposed here differs from the Psyllidae of Burckhardt \& Ouvrard (2012) in the addition of Diaphorina and Katacephala (from Liviidae, Euphyllurinae) as two distinct, basal clades, though inclusion of Diaphorina in Psyllidae requires further testing (Percy et al. 2018). The molecular analyses further suggest that the subfamily Psyllinae of Burckhardt \& Ouvrard (2012) is polyphyletic. Here we remove Amorphicola and Platycorypha and assign them each to a new subfamily. An unnamed taxon from Madagascar, also warranting subfamily status, is not further treated here as it contains no described genus and species.

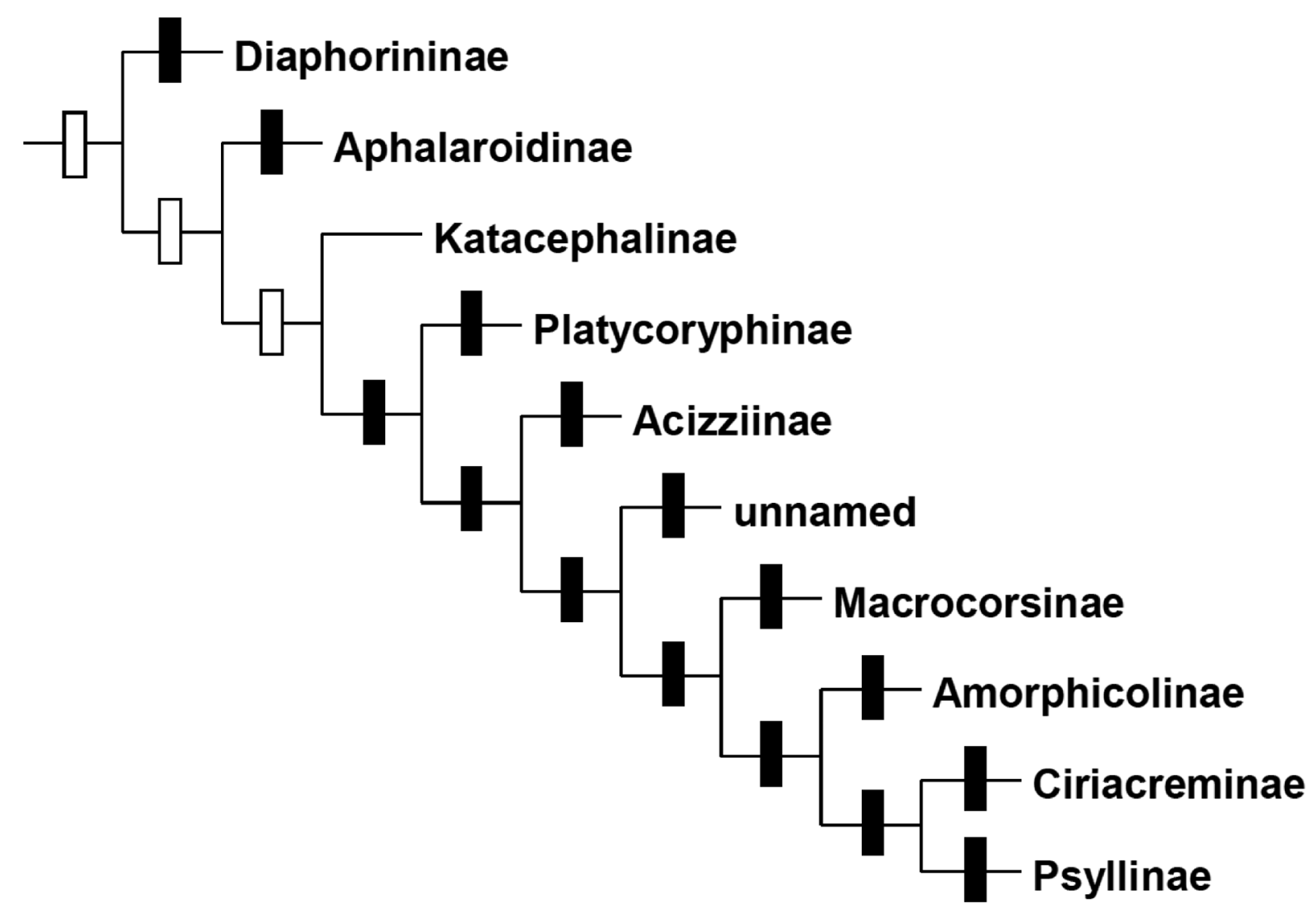

Fig. 4. Cladogram representation of the classification of Psyllidae Latreille, 1807 adopted here, node symbols indicate subfamilies with poor to moderate support (white), or strong support (black) in molecular analyses (Percy et al. 2018). For Katacephalinae subfam. nov. no node symbol is given as only a single species was included in the analyses. 
Subfamily *Acizziinae White \& Hodkinson, 1985

\section{Comments}

The monophyly of Acizziinae is strongly supported in both mtg trees.

\section{Included genus}

* Acizzia Heslop-Harrison, 1961 (replacement name for Neopsylla Heslop-Harrison nec Wagner; syn. Neoacizzia Park \& Taylor nomen nudum [no included species] syn. nov., Neoacizzia Li, 2011)

Subfamily *Amorphicolinae subfam. nov.

urn:lsid:zoobank.org:act:3F17DEF8-6E82-4586-9AA8-ED1325E5D087

Fig. 5

\section{Type genus}

Amorphicola Heslop-Harrison, 1961.

\section{Diagnosis}

\section{Adult}

Vertex separated from genae by transverse suture; genae forming conical processes; coronal suture fully developed; frons oval, almost completely covered by median ocellus; anteorbital tubercle and

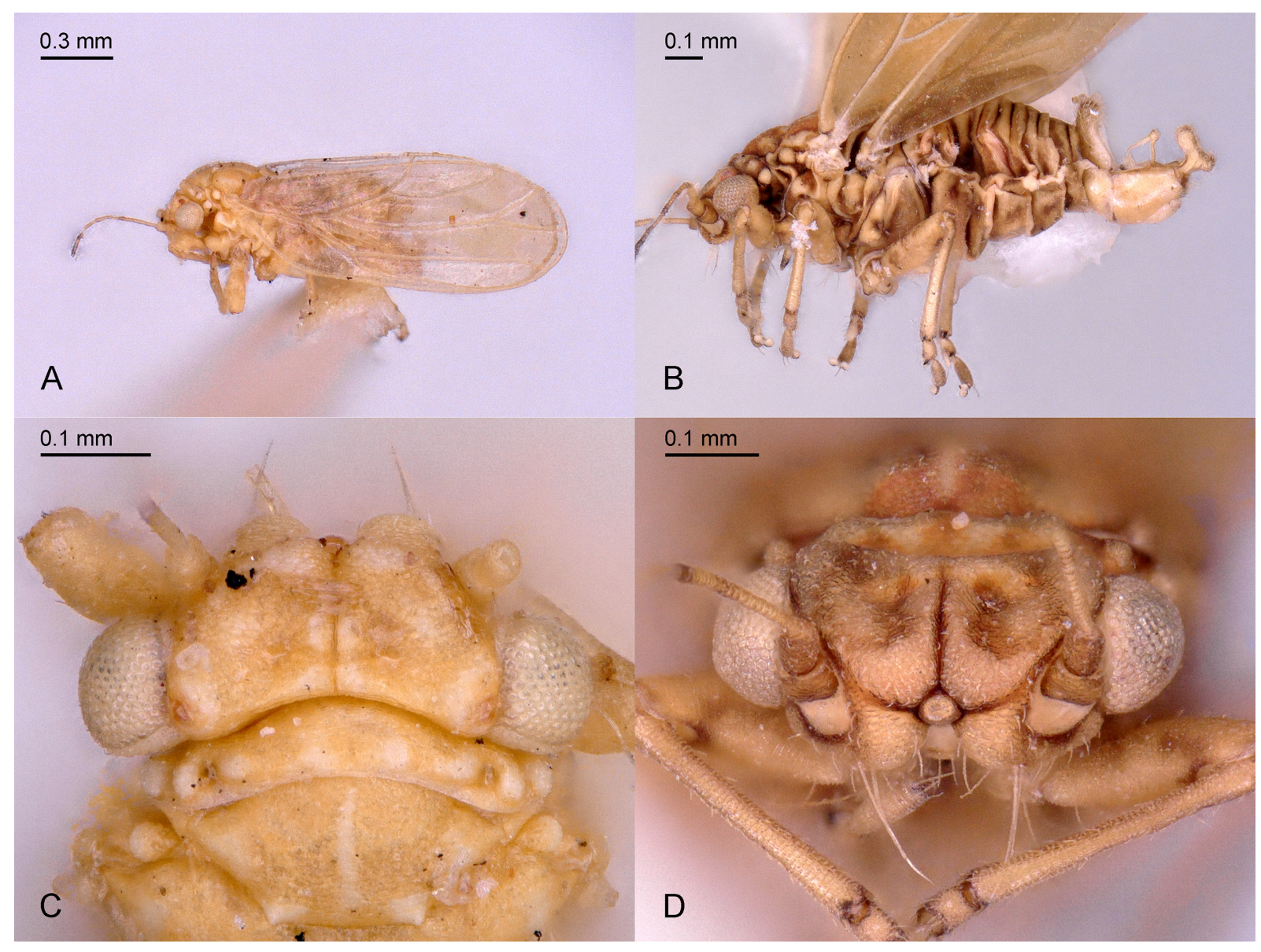

Fig. 5. Amorphicolinae subfam. nov.: Amorphicola sp. A. Habitus, in profile view. B. Legs and terminalia. C. Head, dorsal view. D. Head, frontal view. 
preocular sclerite absent. Antenna with segment 3 longer than segments 7 or 8 . Thorax moderately arched dorsally; propleurites with subequal epimeron and episternum. Metatibia without genual spine, bearing 4 irregularly spaced, sclerotised, apical spurs; metabasitarsus with 2 spurs. Forewing rhomboidal, broadly rounded apically; membrane semitransparent; costal break developed, pterostigma large; anal break close to apex of vein $\mathrm{Cu}_{1 \mathrm{~b}}$. Hindwing with grouped costal setae; vein $\mathrm{M}+\mathrm{Cu}$ developed. Male proctiger one-segmented; in profile, tubular. Paramere complex, in profile axe or hammer-shaped with several sclerotised peg setae on the inner face.

\section{Fifth instar immature}

Body flattened, broadly oval. Antenna 7-segmented, beset with a few short club-shaped setae. Forewing pad lacking humeral lobes, bearing short marginal club-shaped setae. Margin of hindwing pad with club-shaped or capitate setae. Tarsal arolium lacking pedicel. Caudal plate with 4+4 marginal sectasetae and some moderately long club-shaped setae. Anus in ventral position; circumanal ring heart-shaped, consisting of a single row of pores, lacking additional pore fields.

\section{Description}

\section{Adult}

Head, in profile, weakly to moderately inclined at $30-45^{\circ}$ from longitudinal body axis (Fig. 5A-B). Vertex subtrapezoidal, separated from genae by transverse suture; genae forming conical processes which are separated or contiguous at base; coronal suture fully developed; frons oval, almost completely covered by median ocellus; anteorbital tubercle and preocular sclerite not developed (Fig. 5C-D). Antenna 10-segmented, filiform, 1.0-1.5 times as long as head width, segment 3 longer than segments 7 or 8. Clypeus pear-shaped, slightly flattened, hardly visible in profile. Rostrum short, distinctly exceeding procoxae. Thorax moderately arched dorsally (Fig. 5A-B), slightly narrower than head; pronotum ribbon-shaped; mesopraescutum in longitudinal body axis about as long as mesoscutum; propleurites with subequal epimeron and episternum. Legs moderately long, tibiae slightly longer than femora; basitarsi not much longer than broad; metacoxa with moderately large, horn-shaped meracanthus; metatibia without genual spine, bearing 4 irregularly spaced, sclerotised, apical spurs; metabasitarsus with 2 spurs (Fig. 5B). Forewing rhomboidal, broadly rounded apically (Fig. 5A); membrane semitransparent, covered in irregularly spaced surface spinules; costal break developed, pterostigma large; vein $\mathrm{R}$ longer than $\mathrm{M}+\mathrm{Cu}$; anal break close to apex of vein $\mathrm{Cu}_{1 \mathrm{~b}}$. Hindwing almost as long as forewing, membranous; costal setae grouped; vein $\mathrm{M}+\mathrm{Cu}$ developed. Male proctiger onesegmented; in profile, tubular. Male subgenital plate subglobular or elongate. Paramere complex, in profile hammer-shaped (Fig. 5B) with several sclerotised peg setae on the inner face. Female terminalia cuneate. Circumanal ring oval.

\section{Fifth instar immature}

Body flattened, broadly oval. Antenna 7-segmented, beset with a few short club-shaped setae; bearing a single subapical rhinarium on each of segments 3 and 5, and 2 rhinaria on segment 7 . Forewing pad lacking humeral lobes, bearing short marginal club-shaped setae. Margin of hindwing pad with clubshaped or capitate setae. Legs bearing club-shaped or capitate setae; tarsal arolium longer than claws, fan-shaped with unguitractor but lacking pedicel. Caudal plate developed, semi-circular; margin with $4+4$ sectasetae and some moderately long club-shaped setae. Anus in ventral position; circumanal ring heart-shaped, consisting of a single row of pores, without additional pore fields.

\section{Included genus}

*Amorphicola Heslop-Harrison, 1961. 
BURCKHARDT D. et al., Updated classification of the jumping plant-lice

Subfamily *Aphalaroidinae Vondráček, 1963

Arepuniinae White \& Hodkinson, 1985: 271 (misspelling).

\section{Comments}

The monophyly of Aphalaroidinae as understood here is strongly supported in both $\mathrm{mtg}$ trees and it is well circumscribed morphologically (Burckhardt 1987). The molecular analyses place Telmapsylla, which was previously included in the Aphalaroidinae (Burckhardt \& Ouvrard 2012), in Ciriacreminae; we therefore transfer this genus to Ciriacreminae. Burckhardt \& Ouvrard (2012) treated Primascena $\dagger$ as a synonym of Diclidophlebia (Liviidae: Liviinae). However, the presence of metabasitarsal spurs and a crown of spaced apical spurs on the metatibia in P. subita $\dagger$ Klimaszewski, 1998, the type species of Primascenat, indicate a relationship to Aphalaroidinae, as suggested by Burckhardt \& Mifsud (2003). We follow the latter authors and recognise Primascenat, stat. rev., as a valid genus in the Aphalaroidinae.

The internal phylogenetic relationships were discussed by Burckhardt $(1987,2005)$ but there is no explicit, testable hypothesis. In the molecular analyses, where only three of the 13 currently recognised genera were included, the sister group relationship between Aphalaroida and Russelliana is only poorly supported.

\section{Included genera}

* Aphalaroida Crawford, 1914; Baccharopelma Burckhardt et al., 2004 (replacement name for Neopelma Burckhardt nec Sclater, Burckhardtia Straube \& Meritzki nec Frech, nec Brown \& Hodkinson); Connectopelma Šulc, 1914 (replacement name for Delina Blanchard nec Robineau-Desvoidy); Ehrendorferiana Burckhardt, 2005; *Freysuila Aleman, 1887 (syn. Indana); Pachyparia Loginova, 1967; Panisopelma Enderlein, 1910; Primascena† Klimaszewski, 1998, stat. rev.; Prosopidopsylla Burckhardt, 1987; *Russelliana Tuthill, 1959 (syn. Arepuna); Sphinia Blanchard, 1852; Yangus Fang, 1990 (syn. Pallipsylla); Zonopelma Burckhardt, 1987.

Subfamily *Ciriacreminae Enderlein, 1910

\section{Comments}

The monophyly of Ciriacreminae is strongly supported in both mtg trees and its circumscription corresponds mostly to that of Burckhardt \& Ouvrard (2012) with the addition of Telmapsylla Hodkinson, 1992, Caradocia Laing, 1923, Epipsylla Kuwayama, 1908 and Geijerolyma Froggatt, 1903 which are included here. However, all five Old World and two additional New World genera listed by Burckhardt \& Ouvrard (2012) are not included in the molecular analyses. In both mtg trees, the monophyly of Auchmerina, Euceropsylla + Heteropsylla, of Telmapsylla+'Limbopsylla' lagunculariae and of Mitrapsylla+'Limbopsylla' nigrivenis, as well as the sister group relationship of the first two groups is very strongly supported.

The artificial nature of Limbopsylla was acknowledged by Brown \& Hodkinson (1988) when erecting the genus. The type species is a member of Platycoryphinae subfam. nov. (see there for more details). Two species of 'Limbopsylla' included in the molecular analysis are placed in the Ciriacreminae: 'Limbopsylla' lagunculariae and 'Limbopsylla' nigrivenis. We transfer here the former to Telmapsylla and assign the second to the new genus Hollisiana gen. nov. (see Table 1 and description below).

'Limbopsylla' lagunculariae (Brown \& Hodkinson, 1988) comb. nov. and Telmapsylla minuta Hodkinson, 1992 constitute a very strongly supported monophyletic clade in both $\mathrm{mtg}$ trees. Morphologically, the two species share the head with a trapezoidal vertex, the lack of anteorbital tubercles, the hemispherical, adpressed eyes, the conical, apically pointed genal processes, the large $\mathrm{cu}_{1}$ cell of the forewing, the 
Table 1. Species in Psyllidae originally assigned to Limbopsylla Brown \& Hodkinson, 1988 and their current generic placement.

\begin{tabular}{|c|c|c|}
\hline Species list & Valid generic assignment & Authority \\
\hline Limbopsylla beeryi (Caldwell, 1944) & Apsyllopsis mexicana (Crawford, 1914) & Burckhardt \& Queiroz (2020) \\
\hline $\begin{array}{l}\text { Limbopsylla boquetensis } \\
\text { Brown \& Hodkinson, } 1988\end{array}$ & $\begin{array}{l}\text { Heteropsylla boquetensis } \\
\text { (Brown \& Hodkinson, 1988) }\end{array}$ & Muddiman et al. (1992) \\
\hline $\begin{array}{l}\text { Limbopsylla campanellai } \\
\text { Brown \& Hodkinson, } 1988\end{array}$ & $\begin{array}{l}\text { Euphalerus campanellai } \\
\text { (Brown \& Hodkinson, 1988) }\end{array}$ & Hollis \& Martin (1997) \\
\hline $\begin{array}{l}\text { Limbopsylla caradociforma } \\
\text { Brown \& Hodkinson, } 1988\end{array}$ & $\begin{array}{l}\text { Hollisiana caradociforma } \\
\text { (Brown \& Hodkinson, 1988) comb. nov. }\end{array}$ & comb. nov. \\
\hline Limbopsylla chirui Brown \& Hodkinson, 1988 & $\begin{array}{l}\text { not congeneric with } L . \text { nata } \\
\text { (placement to be determined) }\end{array}$ & \\
\hline Limbopsylla estribii Brown \& Hodkinson, 1988 & $\begin{array}{l}\text { not congeneric with } L . \text { nata } \\
\text { (placement to be determined) }\end{array}$ & \\
\hline $\begin{array}{l}\text { Limbopsylla lagunculariae } \\
\text { Brown \& Hodkinson, } 1988\end{array}$ & $\begin{array}{l}\text { Telmapsylla lagunculariae } \\
\text { (Brown \& Hodkinson, 1988) comb. nov. }\end{array}$ & comb. nov. \\
\hline Limbopsylla nata Brown \& Hodkinson, 1988 & type species of Limbopsylla & Brown \& Hodkinson (1988) \\
\hline $\begin{array}{l}\text { Limbopsylla nigrivenis } \\
\text { Brown \& Hodkinson, } 1988\end{array}$ & $\begin{array}{l}\text { Hollisiana nigrivenis } \\
\text { (Brown \& Hodkinson, 1988) comb. nov. }\end{array}$ & comb. nov. \\
\hline $\begin{array}{l}\text { Limbopsylla tumidicosta } \\
\text { Brown \& Hodkinson, } 1988\end{array}$ & $\begin{array}{l}\text { not congeneric with } L . \text { nata } \\
\text { (placement to be determined) }\end{array}$ & \\
\hline $\begin{array}{l}\text { Limbopsylla sp. A of } \\
\text { Brown \& Hodkinson, } 1988\end{array}$ & $\begin{array}{l}\text { not congeneric with } L . \text { nata } \\
\text { (placement to be determined) }\end{array}$ & \\
\hline
\end{tabular}

presence of a $\mathrm{M}+\mathrm{Cu}$ vein in the hindwing, the grouped apical metatibial spurs and the short female terminalia in the adult; and immatures with 7-segmented antenna, fan-shaped tarsal arolium with an unguitractor and a short petiole, and $4+4$ marginal sectasetae on the caudal plate. Despite many morphological differences between the two species, such as antennal length, absence/presence of a genual spine and details of the male terminalia in the adult, and the number of rows of pores in the circumanal ring, we consider them congeneric and propose the following new combination: Telmapsylla lagunculariae (Brown \& Hodkinson, 1988) comb. nov. from Limbopsylla.

Here, we move three genera which were not treated in the molecular analyses from Liviidae: Euphyllurinae (Diaphorinini) to the Ciriacreminae. Caradocia, Epipsylla and Geijerolyma constitute together a putative monophyletic group based on the presence of long genal processes, very long antennae, metatibia lacking a genual spine but bearing an open crown of densely spaced apical spurs, and two sclerotised spurs on the metabasitarsus. According to White \& Hodkinson (1985), immatures of Epipsylla lack sectasetae on the abdominal margin. While we confirm this for an Asian species (Thailand, NHMB), this is not the case for Afrotropical taxa (material examined from Cameroon, NHMB), where the immatures are similar to those of Mitrapsylla with four sectasetae present on the abdominal margin, two grouped together and each situated on a small tubercle, and with the circumanal ring extending to the abdominal dorsum and consisting of several rows of wax pores. The combination of the last two characters can be found only in the Ciriacreminae.

\section{Included genera}

*Auchmerina Enderlein, 1918; Auchmeriniella Brown \& Hodkinson, 1988; Caradocia Laing, 1923; Ciriacremum Enderlein, 1910 (syn. Bunoparia); Epipsylla Kuwayama, 1908; *Euceropsylla Boselli, 1929 (syn. Aremica); Geijerolyma Froggatt, 1903; *Heteropsylla Crawford, 1914; *Hollisiana gen. nov.; Insnesia Tuthill, 1964; Isogonoceraia Tuthill, 1964; Jataiba Burckhardt \& Queiroz, 2020; Kleiniella Aulmann, 1912 (syn. Desmiostigma, Syndesmophlebia); Manapa Brown \& Hodkinson, 1988; * Mitrapsylla Crawford, 1914; Queiroziella Burckhardt, 2021; Palmapenna Hollis, 1976; *Telmapsylla Hodkinson, 1992; Trigonon Crawford, 1920. 
BURCKHARDT D. et al., Updated classification of the jumping plant-lice

\section{Genus Hollisiana gen. nov. urn:lsid:zoobank.org:act:2DDCB705-CCB8-442F-8EAC-B3050DF0192A}

Fig. 6

\section{Type species}

Limbopsylla nigrivenis Brown \& Hodkinson, 1988; by present designation. Gender feminine.

\section{Etymology}

This genus is dedicated to David Hollis for his outstanding contribution to psyllid systematics.

\section{Description}

\section{Adult}

See also Brown \& Hodkinson 1988: figs 63-64 for illustrations. Moderately large psyllids, 2.5-5.0 mm long. Head about as wide as mesonotum, inclined at $45^{\circ}$ from longitudinal body axis (Fig. 6A-B). Vertex trapezoidal, about 1.8 times as wide as long along midline, weakly indented around foveae; passing smoothly into genae not separated by transverse suture; genae produced into long conical processes which are covered in conspicuous long setae; median suture complete, reaching hind margin of head; lateral ocelli on small tubercles; frons forming small rhomboid sclerite, delimited by vertex and genae, almost completely covered by median ocellus; compound eyes relatively small, hemispherical, stalked on large preocular sclerite and occiput (Fig. 6C-D). Clypeus hidden by genae in lateral view, pear-shaped; rostrum short, only apex visible in lateral view. Antenna filiform, longer than forewing, 10-segmented, in some species flagellum getting thinner towards apex; flagellum beset with long conspicuous bristles; segment 3 shorter than segments 7 or 8 , with a single subapical rhinarium on each of segments 4,6 , 8 , and 9; terminal setae shorter than segment 10 . Thorax weakly arched dorsally; lacking macroscopic setae. Pronotum transversely ribbon-shaped.

Propleurites about as broad as high, slightly oblique; proepimeron as big as or larger than episternum. Forewing oval, broadly, irregularly rounded apically, transparent, more than twice as long as wide; pterostigma lacking; costal break present, indistinct; cells $\mathrm{m}_{1}$ and $\mathrm{cu}_{1}$ large; anal break close to apex of vein $\mathrm{Cu}_{1 b}$. Hindwing slightly shorter than forewing; costal setae grouped; vein $\mathrm{R}$ and $\mathrm{M}+\mathrm{Cu}$. Metacoxa with large, horn-shaped, pointed meracanthus; metafemur slightly shorter than metatibia; metatibia bearing genual spine and $1+3+1$ apical spurs. Metabasitarsus with two lateral spurs. Male proctiger unipartite, tubular or with posterior lobe. Subgenital plate elongate. Paramere slender, lamellar or digitiform. Aedeagus long and thin; distal segment shorter than paramere, inflated in apical third; sclerotised end tube of ductus ejaculatorius short, slightly sinuous. Female terminalia, in profile, cuneate, moderately short to relatively long. Circumanal ring oval, consisting of two subequal rows of pores. Valvulae triangular and lacking serrations.

Fifth instar immature (Fig. 6E-H)

Body elongate, about twice as long as wide (Fig. 6G-H). Antenna 9-segmented, sparsely beset with a few short setae; bearing a single subapical rhinarium on each of segments $4,6,8$ and 9. Forewing pad small, lacking humeral lobes, bearing short marginal club-shaped setae. Margin of hindwing pad with short bristles. Legs long, with at least one moderately long capitate seta on tibiae; tarsal arolium about twice as long as claws, fan-shaped with unguitractor and pedicel. Abdomen slender; caudal plate weakly sclerotised; abdominal margin with $6+6$ sectasetae, the two at the rear close together and each on a small tubercle and, in some species, distinctly larger than the remainder. Anus in terminal position; circumanal ring extending to the abdominal dorsum and consisting of several rows of wax pores.

\section{Distribution}

Neotropical. 


\section{Host plant and biology}

Guatteria spp. (Annonaceae). Immatures secrete long wax threads from sectasetae at the abdominal apex. In a species from Brazil (Roraima) and Costa Rica, these terminal wax threads form two conspicuous spiral filaments (Fig. 6E-H) (Hanson \& Nishida 2016: 89; Burckhardt 2017: 34).

\section{Comments}

Hollisiana gen. nov. is similar to Mitrapsylla from which it differs in the absence of a pterostigma in the adults; and the narrow abdomen with $6+6$ marginal sectasetae (rather than $4+4$ ) in the fifth instar immature.

Two species are included in the new genus: Hollisiana caradociforma (Brown \& Hodkinson, 1988) gen. et comb. nov. and Hollisiana nigrivenis (Brown \& Hodkinson, 1988) gen. et comb. nov., both from Limbopsylla. The two species differ in the forewing pattern (colourless or fumate versus conspicuously dark veins), male proctiger (absence versus presence of a posterior lobe), female terminalia (long versus

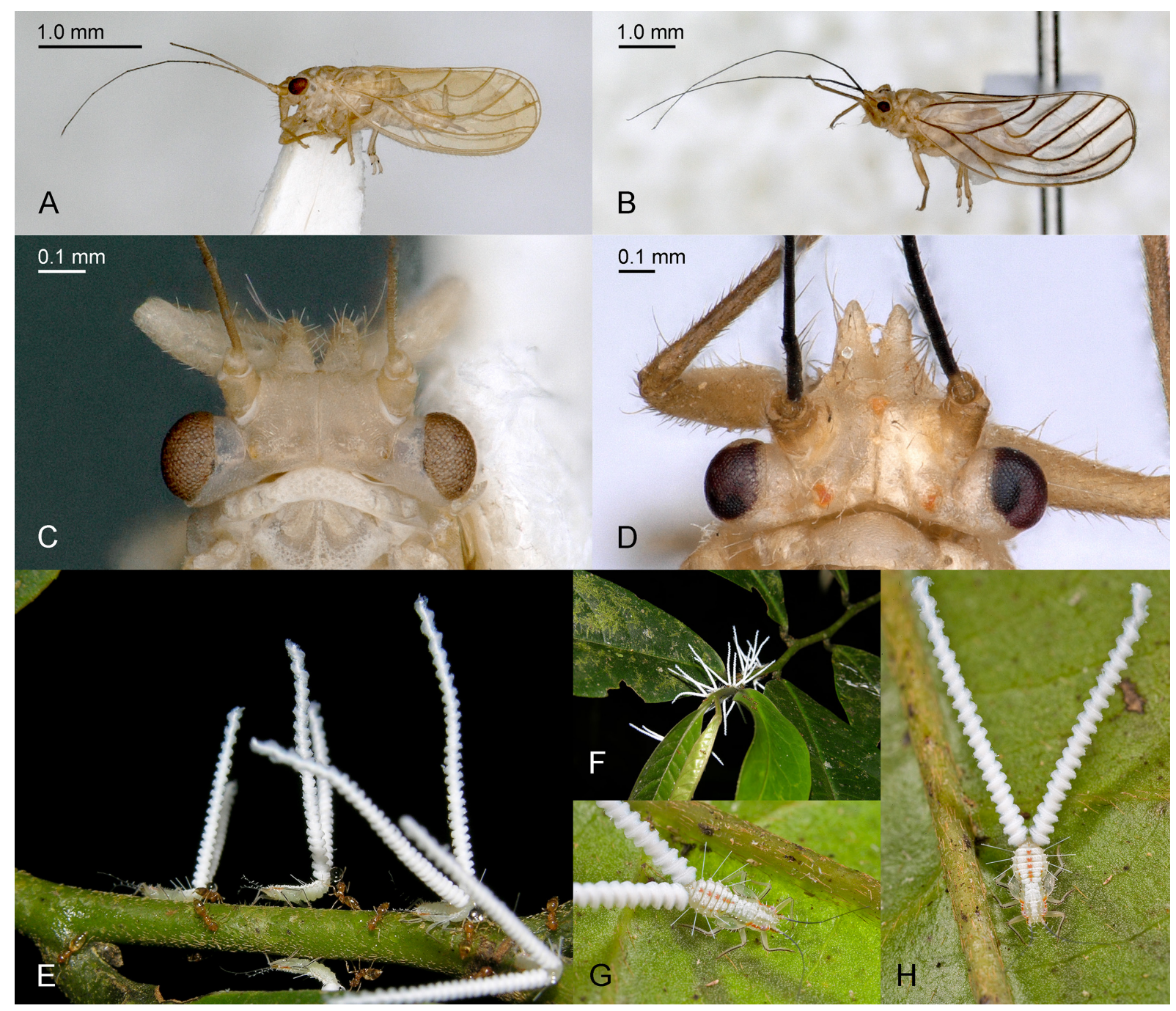

Fig. 6. Ciriacreminae Enderlein, 1910: Hollisiana spp. A, C. Hollisiana caradociforma (Brown \& Hodkinson, 1988) gen. et comb. nov. B, D. Hollisiana sp. from Brazil. E-H. Hollisiana sp. from Costa Rica. A-B. Habitus, in profile view. C-D. Head, dorsal view. E. Immatures tended by ants. F-H. Immatures with spiral filaments. (Photos E-F by Kenji Nishida; G-H by Piotr Naskrecki). 
short), abdomen of immatures (elongate oval versus narrow almost parallel-sided). The two species each represent a species group with more undescribed species in tropical America (BMNH, NHMB data).

\section{Subfamily *Diaphorininae Vondráček, 1951}

\section{Comments}

The AN tree (but not the CC tree) shows reasonably strong support for a sister group relationship of Diaphorina to the remainder of Psyllidae, and, as noted earlier, reduced taxon nuclear genome and combined data analyses by Percy et al. (2018) place Diaphorina outside Psyllidae and sister to Triozidae. Increased taxon sampling and more analyses are required to robustly resolve this ambiguity, and therefore erection of a separate family is currently rejected in favour of inclusion in Psyllidae at this time. Based on the morphology of head, forewings and male terminalia we consider Parapsylla the sister group of Diaphorina and include it in the Diaphorininae.

\section{Included genera}

*Diaphorina Löw, 1880 (replacement name for Diaphora Löw nec Stephens, syn. Brachypsylla, Gonanoplicus, Pennavena, Eudiaphorina); Parapsylla Heslop-Harrison, 1961 (syn. Agmapsylla).

Subfamily *Katacephalinae subfam. nov. urn:lsid:zoobank.org:act:DE4F5C17-6685-47B9-9659-CEFD8828244D

Fig. 7

\section{Type genus}

Katacephala Crawford, 1914.

\section{Diagnosis}

Adult

Head with genae forming conical to lobular processes; preocular sclerite developed. Antenna 10-segmented, 0.9-2.2 times as long as head width, segment 3 usually longer than segments 7 or 8 . Metatibia usually without genual spine, bearing an open crown of 6-19 evenly spaced, sclerotised, apical spurs; metabasitarsus usually with 2 spurs. Forewing with costal break and large pterostigma; anal break close to apex of vein $\mathrm{Cu}_{1 \mathrm{~b}}$. Hindwing almost as long as forewing. Male proctiger one-segmented, in profile, often with posterior lobes. Paramere usually simple with stout setae on the inner face.

\section{Fifth instar immature}

Body often bearing lanceolate setae or sectasetae but lacking capitate setae. Antenna 7-10 segmented with 4 rhinaria. Tarsal arolium fan-shaped, unguitractor developed.

\section{Description}

\section{Adult}

Head, in profile, hardly to strongly (Fig. 7A-F) inclined at $0-90^{\circ}$ from longitudinal body axis. Vertex trapezoidal (Fig. 7J) to almost subrectangular (Fig. 7L), separated from genae by transverse suture; genae forming conical to lobular processes which are separated or contiguous medially; coronal suture usually fully developed (Fig. 7G, I-L) but sometimes reduced (Fig. 6H); frons small, almost completely covered by median ocellus; anteorbital tubercle rarely developed (Fig. 7L: arrow); preocular sclerite always present (Fig. 7J: arrow). Antenna 10-segmented, filiform, 0.9-2.2 times as long as head width, segment 3 ususally longer than segments 7 or 8 (except for some species of Tuthillia). Clypeus pearshaped, flattened in Tuthillia; hardly or not visible in profile. Rostrum short, distinctly exceeding procoxae. Thorax weakly (Fig. 7F) to strongly (Fig. 7B) arched dorsally, as wide as or wider than head; pronotum transversely ribbon-shaped; mesopraescutum in longitudinal body axis slightly to distinctly 


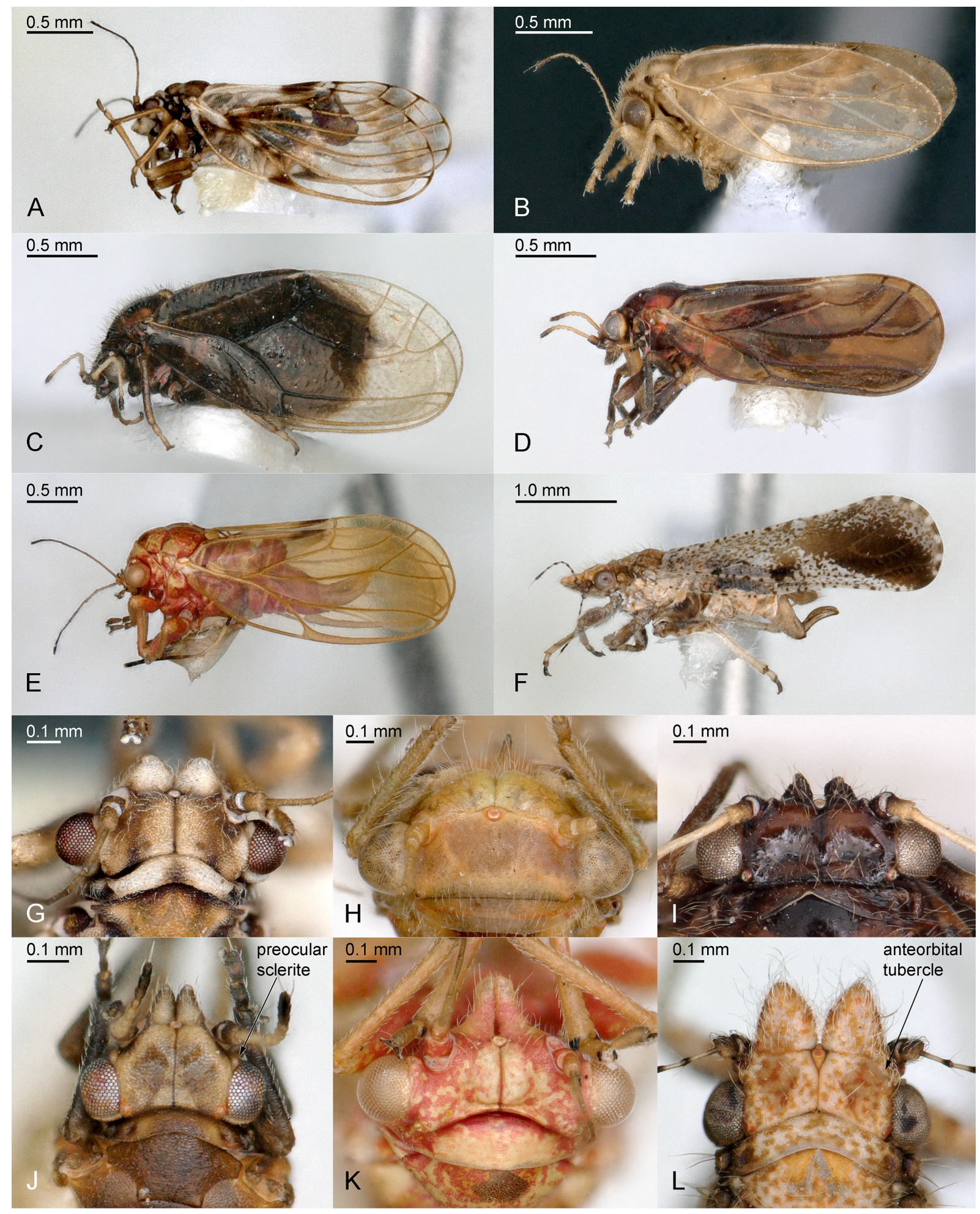

Fig. 7. Katacephalinae subfam. nov. A, G. Katacephala longiramis (Burckhardt, 1987). B. Katacephala tenuipennis Tuthill, 1944. C, I. Lautereropsis sp. D, J. Notophorina brevicornis Burckhardt, 1987. E, K. Notophorina sp. F, L. Tuthillia sp. H. Katacephala sp. A-F. Habitus, in profile view. G-L. Head, dorsal view. 
shorter than mesoscutum; propleurites narrow or broad, relative sizes of epimeron and episterum variable. Legs moderately long, tibiae longer than femora; basitarsi slightly longer than to about twice as long as broad; metacoxa with large, horn-shaped meracanthus; metatibia without genual spine (exception Notophorina vitripennis Burckhardt, 1987), bearing an open crown of 6-19 evenly spaced, sclerotised, apical spurs; metabasitarsus with 2 spurs (exception Notophorina monocentra Burckhardt, 1987). Forewing oval (Fig. 7B), somewhat rectangular, rhomboidal or very elongate (Fig. 7F), narrowly (Fig. 7B) to broadly rounded apically (Fig. 7C); membrane semitransparent, sometimes with pattern; costal break developed, pterostigma large; anal break close to apex of vein $\mathrm{Cu}_{1 b}$. Hindwing almost as long as forewing, membranous; costal setae indistinctly to clearly grouped; vein $\mathrm{R}+\mathrm{M}+\mathrm{Cu}$ branching into veins $\mathrm{R}+\mathrm{M}$ and $\mathrm{Cu}$ or $\mathrm{R}$ and $\mathrm{M}+\mathrm{Cu}$. Male proctiger one-segmented, in profile, often with posterior lobes. Male subgenital plate subglobular or elongate. Paramere usually simple with stout setae on the inner face. Female terminalia cuneate or falcate. Circumanal ring oval.

\section{Fifth instar immature}

Body oval to elongate, fairly robust; surface often covered in lanceolate setae or sectasetae but lacking capitate setae. Antenna 7-10 segmented with 4 rhinaria. Dorsal thoracic sclerites varying from small to large. Tarsal arolium fan-shaped, unguitractor developed, pedicel absent or present. Forewing-pads often with large humeral lobes. Anus in ventral or terminal position. Circumanal ring variable.

\section{Comments}

The four genera included in the new subfamily were assigned by Burckhardt \& Ouvrard (2012) to the polyphyletic tribe Diaphorinini (Euphyllurinae) along with other genera referred here to Euphyllurinae (Liviidae), Ciriacreminae, Diaphorininae and Psyllinae (Psyllidae). Putative autapomorphies of the new subfamily are the open crown of densely spaced metatibial spurs and the posteriorly lobed male proctiger in adults, as well as the presence of lanceolate setae and the lack of capitate setae in immatures. Hosts of the Oriental Lautereropsis Burckhardt \& Malenovský, 2003 are unknown. The other three genera are associated entirely or partially with Myrtaceae and are mostly Neotropical.

\section{Included genera}

*Katacephala Crawford, 1914 (syn. Jenseniella); Lautereropsis Burckhardt \& Malenovský, 2003; Notophorina Burckhardt, 1987; Tuthillia Hodkinson, Brown \& Burckhardt, 1986.

Subfamily *Macrocorsinae Vondráček, 1963

Euphalerini Bekker-Migdisova, 1973: 112.

\section{Comments}

The monophyly of Macrocorsinae is very strongly supported in both mtg analyses. The four genera treated in the analyses are also assigned to this subfamily by Burckhardt \& Ouvrard (2012) who included another eight genera. Meanwhile, Euphaleropsis and Peregrinivena were synonymised (Burckhardt et al. 2018b). Trisetipsylla was placed in the Macrocorsinae by Cho et al. (2019) rather that in Psyllinae (Burckhardt \& Ouvrard 2012). At least some species of Trisetipsylla have immatures with extra pore fields on the caudal plate, supporting this placement.

Otroacizzia† Klimaszewski, 1996 contains the following species: O. muta† Klimaszewski, 1996 (type species), O. prosapia † Klimaszewski, 1996, O. soriae $\dagger$ Peñalver \& García-Gimeno, 2006 and O. tertia $\dagger$ Klimaszewski, 1996. Burckhardt \& Ouvrard (2012) synonymised Otroacizzia with Euryconus.

A reevaluation of the status of the four fossil species by Klimaszewski (1996) and Peñalver \& GarcíaGimeno (2006) showed that Otroacizzia is a species mix referrable to Colophorina (O. muta) and to Euryconus (other species). Whereas the antennae are short and a genual spine is lacking in O. muta, the 
antennae are long and the genual spine is developed in the other three species. Thus, O. muta shows the characteristics of Colophorina, making Otroacizziat a junior synonym of the former. The other three species of Otroacizzia † conform with the diagnosis of Euryconus and are transferred there. The following new synonymy and new combinations are proposed here:

Colophorina Capener, 1973 = Otroacizzia† Klimaszewski, 1996, syn. nov.

Colophorina muta $\dagger$ (Klimaszewski, 1996) comb. nov. from Otroacizzia †

Euryconus prosapia $\dagger$ (Klimaszewski, 1996) comb. nov. from Otroacizzia $\dagger$

Euryconus soriae $\uparrow$ (Peñalver \& García-Gimeno, 2006) comb. nov. from Otroacizzia †

Euryconus tertia $\dagger$ (Klimaszewski, 1996) comb. nov. from Otroacizzia †

\section{Included genera}

Apsyllopsis Burckhardt \& Queiroz, 2020; Brinckitia Heslop-Harrison, 1961; *Colophorina Capener, 1973 (syn. Otroacizzia†, syn. nov.); *Epiacizzia Li, 2002; Euphaleropsis Li, 2004 (syn. Peregrinivena); *Euphalerus Schwarz, 1904; Euryconus Aulmann, 1912; Macrocorsa Vondráček, 1963; *Paraphyllura Yang, 1984; Pugionipsylla Li in Li et al., 2006; Retroacizzia Heslop-Harrison, 1961; Tridencopsylla Li, 2002; Trisetipsylla Yang \& Li, 1984.

Subfamily *Platycoryphinae subfam. nov. urn:1sid:zoobank.org:act:B8BF6738-548A-4042-A942-7A21085A3973

Fig. 8

\section{Type genus}

Platycorypha Tuthill, 1945.

\section{Diagnosis}

\section{Adult}

Head with oval frons, which is almost completely covered by median ocellus. Clypeus pear-shaped, in profile hidden by genae and not visible. Propleurites with episternum subequal to or smaller than epimeron. Metacoxa with large, pointed, horn-shaped meracanthus; metatibia with large genual spine, bearing 4-5 irregularly spaced, sclerotised, apical spurs; metabasitarsus with 2 spurs. Forewing rhomboidal; costal break and pterostigma developed; cell $\mathrm{cu}_{1}$ large; anal break close to apex of vein $\mathrm{Cu}_{1 b}$. Male proctiger one-segmented.

\section{Fifth instar immature}

Body broadly oval, lacking capitate setae. Antenna with 4 rhinaria. Meso and metathoracic sclerites small. Forewing pad lacking humeral lobes. Margin of hindwing pad usually with one sectaseta. Legs lacking capitate setae; tarsal arolium fan-shaped with unguitractor and pedicel. Caudal plate developed, semi-circular; margin with up to $3+3$ sectasetae.

\section{Description}

Adult

Head, in profile, weakly to strongly inclined at $30-90^{\circ}$ from longitudinal body axis (Fig. 8A, C, E, G). Vertex subrectangular to transversely subtrapezoidal (Fig. 8B, D, F, H); separated from genae sometimes by transverse or oblique suture, sometimes passing smoothly into genae; genae smoothly rounded (Fig. 8D, H) or forming short (Fig. 7F) or long conical processes (Fig. 8B); coronal suture fully developed or completely reduced; frons oval, almost completely covered by median ocellus; anteorbital tubercle sometimes developed (Fig. 8D: arrow). Antenna 10-segmented, filiform, ranging from slightly longer than head width to distinctly longer than forewing, segment 3 shorter or longer than segments 7 or 8 . Clypeus pear-shaped, in profile hidden by genae and not visible. Rostrum usually short, only 
tip exceeding procoxae, sometimes longer (in some Platycorypha spp.). Thorax weakly (Fig. 7G) to strongly (Fig. 8A) arched dorsally, about as wide as head; pronotum weakly or very strongly inclined from longitudinal body axis; propleurites narrow to broad, with episternum subequal to or smaller than epimeron. Legs moderately long, tibiae often shorter than femora, sometimes subequal or longer; basitarsi not much longer than broad; metacoxa with large, pointed, horn-shaped meracanthus; metatibia with large genual spine, bearing 4-5 irregularly spaced, sclerotised, apical spurs; metabasitarsus with 2 spurs. Forewing rhomboidal, broadest in apical third or in the middle, narrowly rounded or angular apically; membrane semitransparent, covered in surface spinules; costal break and pterostigma developed; vein $\mathrm{C}+\mathrm{Sc}$ weakly or strongly widened; vein $\mathrm{R}$ longer than $\mathrm{M}+\mathrm{Cu}$; cell $\mathrm{cu}_{1}$ large; caudal break close to apex of vein $\mathrm{Cu}_{1 b}$. Hindwing slightly shorter than forewing, membranous; costal setae ungrouped or grouped;

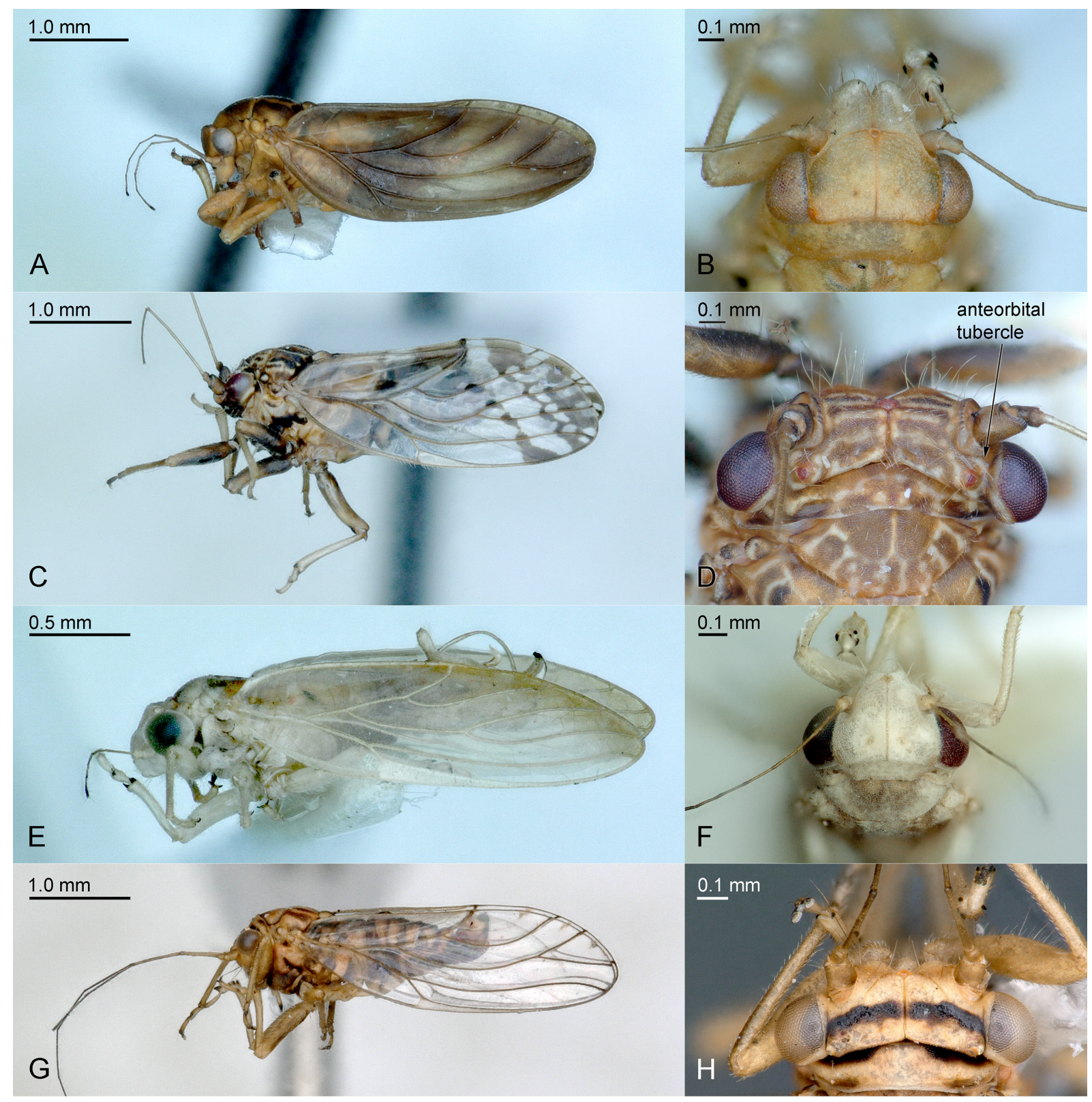

Fig. 8. Platycoryphinae subfam. nov. A-B. Allophorina sp. C-D. Limbopsylla nata Brown \& Hodkinson, 1988. E-F. Padaukia macrolobii Burckhardt \& Queiroz, 2018. G-H. Platycorypha nigrivirga Burckhardt, 1987. A, C, E, G. Habitus, in profile view. B, D, F, H. Head, dorsal view. 
vein $\mathrm{R}+\mathrm{M}+\mathrm{Cu}$ indistinctly trifurcating or splitting into $\mathrm{R}$ and $\mathrm{M}+\mathrm{Cu}$. Male proctiger one-segmented; in profile, tubular or with posterior lobe. Male subgenital plate subglobular or elongate. Paramere lamellar or complex. Female terminalia short or moderaly long; proctiger often with dorsal hump.

\section{Fifth instar immature}

Body broadly oval, lacking capitate setae. Antenna 7, 9 or 10-segmented, with 4 rhinaria. Meso and metathoracic sclerites small. Forewing pad lacking humeral lobes. Margin of hindwing pad usually with one sectaseta. Legs lacking capitate setae; tarsal arolium shorter or longer than claws, fan-shaped with unguitractor and pedicel. Caudal plate developed, semi-circular; margin with up to $3+3$ sectasetae. Anus in ventral or terminal position; circumanal ring small heart-shaped to large undulate, restricted to ventral side or extended to dorsal side; consisting of a single row or multiple rows of pores, without additional pore fields.

\section{Comments}

Brown \& Hodkinson (1988) created Limbopsylla as a polyphyletic holding place for ten "species of the subfamilies Acizziinae and Ciriacreminae which cannot be placed in existing genera". Three species have been removed previously and three species are transferred here (Table 1). Based on adult and immature material of an undescribed species from Brazil associated with Tachigali rugosa (Fabaceae) (NHMB) which is congeneric with L. nata, the type species of Limbopsylla, we conclude that Limbopsylla is a valid genus closely related to Platycorypha, and that the other species included in Limbopsylla (Table 1) are not congeneric with the type species.

\section{Included genera}

Allophorina Hodkinson, 1991; Limbopsylla Brown \& Hodkinson, 1988; Padaukia Hollis \& Martin, 1993 (syn. Peltapaurocephala Heslop-Harrison nomen nudum, no description); *Platycorypha Tuthill, 1945 (syn. Neopsyllia).

\section{Subfamily *Psyllinae Latreille, 1807}

Arytainini Crawford, 1914: 106.

Alloeoneurini Vondráček, 1951: 127.

Anomoneurini Klimaszewski, 1963: 92.

Cyamophilini Loginova, 1976: 596.

Cacopsyllinae Li, 2011: 744.

Cornopsyllinae Li, 2011: 532. Syn. nov.

\section{Comments}

In both trees, the monophyly of Psyllinae and the division into three monophyletic subgroups is very strongly supported. The most basal clade consists of a single Asian species, viz. Cacopsylla eriobotryae (Yang, 1984). The second clade contains four West Palaearctic genera associated with faboid Fabaceae: Arytaina Foerster, 1848, Arytainilla Loginova, 1972, Arytinnis Percy, 2003 and Livilla Curtis, 1835. The first three are monophyletic, the last is paraphyletic with respect to Arytainilla and Arytinnis, as previously shown by Percy (2003). Livilla ulicis Curtis, 1836, the type species of Livilla, belongs to a very strongly supported clade which is sister group to a poorly supported Arytainilla. Livilla blandula (Horváth, 1905), a species closely related to Livilla pyrenaea (Mink, 1859), the type species of Floria Löw, 1879, and Livilla radiata (Foerster, 1848), the type species of Alloeoneura Löw, 1879, belong to a clade which is sister group to the very strongly supported Arytinnis. To split Livilla s. lat. into two monophyletic genera, viz. Livilla s. str. and Floria (syn. Alloeoneura), respectively, is not practicable at the moment as only a quarter of the known species (see Ouvrard 2020 for a complete list of species) were included in the molecular analyses and no morphological characters are known reflecting these 
groupings. The third clade comprises a very strongly supported group of North American species associated with Ceanothus L. (Rhamnaceae) (= Ceanothia Heslop-Harrison, 1961 and Nyctiphalerus Bliven, 1955, see Table 2), previously referred to the genera Ceanothia, Euglyptoneura HeslopHarrison, 1961 and Nyctiphalerus, which is sister group to a poorly supported clade comprising one clade represented by a single species (Pexopsylla cercocarpi Jensen, 1957) and four very strongly supported clades: 1. holarctic species of Cacopsylla Ossiannilsson, 1970 associated with Elaeagnaceae, Lardizabalaceae, Rosaceae and Salicaceae (= Cacopsylla s. str.); 2. holarctic species associated with Betulaceae (= Psylla s. str., Table 3), previously referred to Baeopelma Enderlein, 1926, Cacopsylla, Chamaepsylla Ossiannilsson, 1970 and Psylla; 3. palaearctic species associated with Buxus (Buxaceae) (= Spanioneura Foerster, 1848, see Table 4), previously referred to Psylla and Spanioneura; 4. North American species associated with Cercocarpus and Purshia (Rosaceae) (= Purshivora Heslop-Harrison, 1961, see Table 2), previously referred to Cacopsylla, Ceanothia, Nyctiphalerus and Purshivora. Cho et al. (2019) transferred Psylla longicauda Konovalova, 1986, an Asian species associated with Prunus, to Spanioneura and provided morphological adult characters to define Psylla s.str. and Spanioneura.

Similar to Arytaina, Arytainilla, Arytinnis and Livilla, associated with brooms (Fabaceae), which constitute a species-rich clade endemic to the Western Palaearctic, a group of Psyllinae radiated in Western North America on Ceanothus (Rhamnaceae) as well as Cercocarpus and Purshia (Rosaceae). North America authors (Crawford 1914; Tuthill 1943b; Jensen 1956, 1957a, 1957b; Bliven 1956, 1958) assigned these species to the genera Arytaina, Euphalerus and Psylla, rendering these genera very artificial, and to two monotypic genera Nyctiphalerus and Pexopsylla. Heslop-Harrison (1961) discussed the North American genera previously referred to Arytaina and, rightly, concluded that they are not congeneric with Arytaina spartii (Hartig, 1841) (= A. genistae (Latreille, 1804)), the type species of Arytaina. He erected the four genera Amorphicola Heslop-Harrison, 1961, Ceanothia, Euglyptoneura and Purshivora. His descriptions are not diagnostic and he also mixed up the figures (fig. 2 concerns Ceanothia and fig. 3 Amorphicola, and not vice versa). Whereas Amorphicola (see Amorphicolinae subfam. nov.) is well characterised by its paramere morphology and by its host associations (Fabaceae), the other three genera are not. Hollis \& Martin (1997) redefined Euphalerus Schwarz, 1904 and suggested that the Nearctic species are not congeneric with Euphalerus nidifex Schwarz, 1904, the type species, or with most of the Neotropical species. Percy et al. (2012) transferred these species to Nyctiphalerus. The molecular analyses shed much needed light on the phylogenetic relationships in this group. There are monophyletic clades associated with Rhamnaceae (Ceanothus) and with Rosaceae (Cercocarpus, Purshia). The former is characterised by immatures with a terminal anus and a large circumanal ring which extends onto the dorsum of the caudal plate, the latter has immatures with a ventral anus and a smaller circumanal ring restricted to the venter of the caudal plate. The clade of Ceanothus comprises one group with the genal processes in a lower plane to that of the vertex and lacking a genual metatibial spine (type species of Ceanothia and Euglyptoneura), and another group with genal processes and vertex flattened and in the same plane and bearing a genual metatibial spine (type species of Nyctiphalerus). The Rosaceae clade also splits into two groups: one bearing metatarsal spurs (type species of Purshivora) and one lacking metatarsal spurs (type species of Pexopsylla). Here we suggest that Ceanothia, Nyctiphalerus, Pexopsylla and Purshivora are good genera, and that Euglyptoneura syn. nov. is a junior synonym of Ceanothia (Table 2).

The Oriental genus Cornopsylla is transferred here from Liviidae, Euphyllurinae, Diaphorinini to Psyllidae, Psyllinae. The position of Cornopsylla within Psyllidae is supported by morphological (Luo et al. 2013) and molecular characters (Cho et al. 2019); in both papers, Cornopsylla was treated as a member of Psyllinae.

Psyllinae is a species-rich subfamily (ca 800 spp., Ouvrard 2020) with many species referred to Cacopsylla s. str. and Psylla s. str. that do not fit the restricted concepts of these genera provided above. Awaiting more studies on these species, we leave them in Cacopsylla s. lat. and Psylla s. lat. 
Table 2 (continued on next page). North American species in Psyllidae Latreille, 1807 associated with Ceanothus (Rhamnaceae) as well as Cerocarpus and Purshia (Rosaceae) referrable to Ceanothia Heslop-Harrison, 1961; Nyctiphalerus Bliven, 1955; Purshivora Heslop-Harrison, 1961; and Pexopsylla Jensen, 1957. Taxa sampled in Percy et al. (2018) are indicated with an asterisk.

\begin{tabular}{|c|c|c|}
\hline Valid combination & Previous combinations & Comments \\
\hline \multicolumn{3}{|c|}{ Host: Ceanothus (Rhamnaceae) } \\
\hline \multicolumn{3}{|c|}{$\begin{array}{l}\text { *Ceanothia Heslop-Harrison, 1961, type-species Arytaina ceanothae Crawford, 1914, by original designation }= \\
\text { Euglyptoneura Heslop-Harrison, 1961: 434, type-species Arytaina minuta Crawford, 1914, by original designation, syn. nov. }\end{array}$} \\
\hline Ceanothia assimilis (Crawford, 1914) & Arytaina assimilis Crawford, 1914 & $\begin{array}{l}\text { transferred by Hodkinson \& Hollis } \\
\text { (1987) }\end{array}$ \\
\hline Ceanothia bicolor (Jensen, 1957) & Arytaina bicolor Jensen, 1957 & $\begin{array}{l}\text { transferred by Hodkinson \& Hollis } \\
\text { (1987) }\end{array}$ \\
\hline Ceanothia boharti (Jensen, 1957) & Arytaina boharti Jensen, 1957 & $\begin{array}{l}\text { transferred by Hodkinson \& Hollis } \\
\text { (1987) }\end{array}$ \\
\hline *Ceanothia ceanothae (Crawford, 1914) & Arytaina ceanothae Crawford, 1914 & $\begin{array}{l}=\text { Arytaina ceanothi, unjustified } \\
\text { emendation by Tuthill }(1943 \mathrm{~b})\end{array}$ \\
\hline Ceanothia essigi (Jensen, 1957) & Arytaina essigi Jensen, 1957 & $\begin{array}{l}\text { transferred by Hodkinson \& Hollis } \\
\text { (1987) }\end{array}$ \\
\hline Ceanothia fuscipennis (Crawford, 1914) & $\begin{array}{l}\text { Arytaina fuscipennis Crawford, 1914; } \\
\text { Euglyptoneura fuscipennis (Crawford, } \\
\text { 1914) }\end{array}$ & comb. nov. \\
\hline *Ceanothia insolita (Tuthill, 1943) & Arytaina insolita Tuthill, 1943 & $\begin{array}{l}\text { transferred by Hodkinson \& Hollis } \\
\text { (1987) }\end{array}$ \\
\hline *Ceanothia minuta (Crawford, 1914) & $\begin{array}{l}\text { Arytaina minuta Crawford, 1914; } \\
\text { Euglyptoneura minuta (Crawford, } \\
\text { 1914) }\end{array}$ & comb. nov. \\
\hline Ceanothia mitella (Jensen, 1957) & Arytaina mitella (Jensen, 1957) & $\begin{array}{l}\text { transferred by Hodkinson \& Hollis } \\
(1987)\end{array}$ \\
\hline *Ceanothia robusta (Crawford, 1914) & $\begin{array}{l}\text { Arytaina robusta Crawford, 1914; } \\
\text { Euglyptoneura robusta (Crawford, } \\
\text { 1914) }\end{array}$ & comb. nov. \\
\hline Ceanothia tardiuscula (Bliven, 1958) & Arytaina tardiuscula Bliven, 1958 & transferred by Hodkinson (1988) \\
\hline \multicolumn{3}{|c|}{ *Nyctiphalerus Bliven, 1955, type-species Nyctiphalerus lynceus, Bliven, 1955, by original designation } \\
\hline Nyctiphalerus dubius (Caldwell, 1944) & Euphalerus dubius Caldwell, 1944 & transferred by Percy et al. (2012) \\
\hline Nyctiphalerus jugovenosus (Tuthill, 1937) & Euphalerus jugovenosus Tuthill, 1937 & transferred by Percy et al. (2012) \\
\hline \multicolumn{3}{|l|}{ Nyctiphalerus lynceus Bliven, 1955} \\
\hline Nyctiphalerus nepos (Bliven, 1956) & Euphalerus nepos Bliven, 1956 & transferred by Percy et al. (2012) \\
\hline Nyctiphalerus propinquus (Crawford, 1914) & Euphalerus propinquus Crawford, 1914 & transferred by Percy et al. (2012) \\
\hline *Nyctiphalerus rugipennis (Crawford, 1914) & Euphalerus rugipennis Crawford, 1914 & transferred by Percy et al. (2012) \\
\hline $\begin{array}{l}\text { *Nyctiphalerus vermiculosus } \\
\text { (Crawford, 1914) }\end{array}$ & $\begin{array}{l}\text { Euphalerus vermiculosus } \\
\text { Crawford, } 1914\end{array}$ & transferred by Percy et al. (2012) \\
\hline \multicolumn{3}{|c|}{ Host: Cercocarpus and Purshia (Rosaceae) } \\
\hline \multicolumn{3}{|c|}{ *Purshivora Heslop-Harrison, 1961, type-species Arytaina chelifera, Crawford, 1914, by original designation } \\
\hline *Purshivora aculeata (Crawford, 1914) & $\begin{array}{l}\text { Arytaina aculeata Crawford, 1914; } \\
\text { Ceanothia aculeata (Crawford, 1914) }\end{array}$ & comb. nov. \\
\hline Purshivora acuminata (Jensen, 1956) & $\begin{array}{l}\text { Psylla acuminata Jensen, 1956; } \\
\text { Cacopsylla acuminata (Jensen, 1956) }\end{array}$ & comb. nov. \\
\hline Purshivora adusta (Tuthill, 1937) & $\begin{array}{l}\text { Euphalerus adustus Tuthill, 1937; } \\
\text { Nyctiphalerus adustus (Tuthill, 1937) }\end{array}$ & comb. nov. \\
\hline *Purshivora brevistigmata (Patch, 1912) & $\begin{array}{l}\text { Psylla brevistigmata Patch, 1912; } \\
\text { Cacopsylla brevistigmata (Patch, 1912) }\end{array}$ & comb. nov. \\
\hline Purshivora cercocarpi (Jensen, 1957) & $\begin{array}{l}\text { Euphalerus cercocarpi Jensen, 1957; } \\
\text { Nyctiphalerus cercocarpi (Jensen, } \\
\text { 1957) }\end{array}$ & comb. nov. \\
\hline
\end{tabular}


BURCKHARDT D. et al., Updated classification of the jumping plant-lice

Table 2 (continued).

\begin{tabular}{|c|c|c|}
\hline Valid combination & Previous combinations & Comments \\
\hline \multicolumn{3}{|c|}{ Host: Cercocarpus and Purshia (Rosaceae) } \\
\hline Purshivora chelifera (Crawford, 1914) & Arytaina chelifera Crawford, 1914 & $\begin{array}{l}\text { transferred by Heslop-Harrison } \\
(1961)\end{array}$ \\
\hline Purshivora coryli (Patch, 1912) & $\begin{array}{l}\text { Psylla coryli Patch, 1912; Cacopsylla } \\
\text { coryli (Patch, 1912) }\end{array}$ & comb. nov. \\
\hline Purshivora difficilis (Tuthill, 1943) & $\begin{array}{l}\text { Psylla difficilis Tuthill, 1943; } \\
\text { Cacopsylla difficilis (Tuthill, 1943) }\end{array}$ & comb. nov. \\
\hline *Purshivora hirsuta (Tuthill, 1938) & $\begin{array}{l}\text { Arytaina hirsuta Tuthill, 1938; } \\
\text { Psylla hirsuta (Tuthill, 1938); Psylla } \\
\text { (Hepatopsylla) hirsuta (Tuthill, 1938); } \\
\text { Cacopsylla hirsuta (Tuthill, 1938) }\end{array}$ & comb. nov. \\
\hline Purshivora idahoensis (Jensen, 1946) & $\begin{array}{l}\text { Euphalerus idahoensis Jensen, 1946; } \\
\text { Nyctiphalerus idahoensis (Jensen, } \\
\text { 1946) }\end{array}$ & comb. nov. \\
\hline Purshivora insignita (Tuthill, 1943) & $\begin{array}{l}\text { Psylla insignita Tuthill, 1943; } \\
\text { Cacopsylla insignita (Tuthill, 1943) }\end{array}$ & comb. nov. \\
\hline Purshivora maculata (Crawford, 1914) & $\begin{array}{l}\text { Psylla maculata Crawford, 1914; } \\
\text { Cacopsylla maculata (Crawford, 1914) }\end{array}$ & comb. nov. \\
\hline Purshivora magna (Crawford, 1914) & $\begin{array}{l}\text { Psylla brevistigmata magna Crawford, } \\
\text { 1914; Psylla (?Thamnopsylla) magna } \\
\text { (Crawford, 1914); Cacopsylla magna } \\
\text { (Crawford, 1914) }\end{array}$ & comb. nov. \\
\hline Purshivora media (Tuthill, 1943) & $\begin{array}{l}\text { Psylla media Tuthill, 1943; Cacopsylla } \\
\text { media (Tuthill, 1943) }\end{array}$ & comb. nov. \\
\hline *Purshivora minuta (Crawford, 1914) & $\begin{array}{l}\text { Psylla minuta Crawford, 1914; Psylla } \\
\text { (?Hepathopsylla) minuta (Crawford, } \\
\text { 1914); Cacopsylla minuta (Crawford, } \\
\text { 1914) }\end{array}$ & comb. nov. \\
\hline Purshivora nigranervosa (Jensen, 1956) & $\begin{array}{l}\text { Psylla nigranervosa Jensen, 1956; } \\
\text { Cacopsylla nigranervosa (Jensen, 1956) }\end{array}$ & comb. nov. \\
\hline Purshivora pubescens (Crawford, 1914) & Arytaina pubescens Crawford, 1914 & $\begin{array}{l}\text { transferred by Heslop-Harrison } \\
\text { (1961) }\end{array}$ \\
\hline Purshivora tantilla (Tuthill, 1937) & $\begin{array}{l}\text { Euphalerus tantillus Tuthill, 1937; } \\
\text { Nyctiphalerus tantillus (Tuthill, 1937) }\end{array}$ & comb. nov. \\
\hline
\end{tabular}

\section{Included genera}

Anomoneura Schwarz in Uhler, 1896; *Arytaina Foerster, 1848 (syn. Amblyrhina, Ataenia, Psyllopa); *Arytainilla Loginova, 1972 (syn. Hispaniola Ramírez Gómez, 1956 nomen nudum [type species not designated], Lindbergia Heslop-Harrison, 1951 nomen nudum [no included species], Lindbergiella Heslop-Harrison, 1961 nomen nudum [type species not designated], Spartina); *Arytinnis Percy, 2003; Astragalita Loginova, 1976; *Cacopsylla Ossiannilsson, 1970 (syn. Edentatipsylla, Hepatopsylla, Osmopsylla, Thamnopsylla, Psyllia Kirkaldy, 1905 nomen nudum); *Ceanothia Heslop-Harrison, 1961 (syn. Euglyptoneura Heslop-Harrison, 1961, syn. nov.); Cornopsylla Li, 1994; Cyamophila Loginova, 1976; Cyamophiliopsis Li, 2011; Cylindropsylla Li, 2011; Gelonopsylla Li, 1992; *Livilla Curtis, 1835 (syn. Alloeoneura, Floria, Floriella); Mecistoneura Li, 2011; *Nyctiphalerus Bliven, 1955; Palaeolindbergiella Heslop-Harrison, 1961; *Pexopsylla Jensen, 1957; Pseudacanthopsylla Samy, 1972; * Psylla Geoffroy, 1762 (syn. Baeopelma syn. nov., Chamaepsylla syn. nov., Psylla (Labyrinthopsylla) syn. nov., Asphagis Enderlein, 1921); *Purshivora Heslop-Harrison, 1961; *Spanioneura Foerster, 1848 (Asphagidella Enderlein, 1921 syn. nov.). 
Table 3. Holarctic species in Psyllinae Latreille, 1807 associated with Betulaceae referrable to Psylla Geoffroy, 1762. Taxa sampled in Percy et al. (2018) are indicated with an asterisk.

\begin{abstract}
Valid combination
Original combination

Comments

Psylla Geoffroy, 1762: 482, type-species: Chermes alni Linnaeus, 1758, by subsequent designation under the plenary powers of the ICZN Opinion 731 (1965); = Asphagis Enderlein, 1921: 120, type-species Chermes fusca Zetterstedt, 1828, by original designation, synonymised by Tuthill (1943b); Baeopelma Enderlein, 1926: 399, type-species Psylla colorata Löw, 1888, by original designation and monotypy, syn. nov.; Chamaepsylla Ossiannilsson, 1970: 140, type-species: Psylla hartigii Flor, 1861, by original designation and monotypy, syn. nov.; Psylla (Labyrinthopsylla) Ossiannilsson, 1970: 140, type-species: Psylla foersteri Flor, 1861, by original designation and monotypy, syn. nov.
\end{abstract}

\begin{tabular}{|c|c|c|}
\hline \multicolumn{3}{|c|}{ Host: Alnus } \\
\hline *Psylla alni (Linnaeus, 1758) & Chermes alni Linnaeus, 1758 & \\
\hline \multicolumn{3}{|l|}{ Psylla alnicola $\mathrm{Li}, 1992$} \\
\hline \multicolumn{3}{|l|}{ Psylla alnifasciata $\mathrm{Li}, 2011$} \\
\hline \multicolumn{3}{|l|}{$\begin{array}{l}\text { Psylla alniformosanaesuga } \\
\text { Lauterer et al., } 1988\end{array}$} \\
\hline \multicolumn{3}{|l|}{ Psylla alpina Foerster, 1848} \\
\hline \multicolumn{3}{|l|}{ Psylla borealis Horváth, 1908} \\
\hline \multicolumn{3}{|l|}{ Psylla caudata Crawford, 1914} \\
\hline \multicolumn{3}{|l|}{ Psylla cordata Tamanini, 1977} \\
\hline \multicolumn{3}{|l|}{ *Psylla floccosa Patch, 1909} \\
\hline *Psylla foersteri Flor, 1861 & & comb. rev. from Baeopelma \\
\hline Psylla fusca (Zetterstedt, 1828) & Chermes fusca Zetterstedt, 1828 & \\
\hline \multicolumn{3}{|l|}{ Psylla magnifera Kuwayama, 1908} \\
\hline Psylla viridescens (Provancher, 1872) & \multicolumn{2}{|l|}{ Diraphia viridescens Provancher, 1872} \\
\hline \multicolumn{3}{|c|}{ Host: Betula } \\
\hline \multicolumn{3}{|l|}{ Psylla ancylocaula Li, 2011} \\
\hline Psylla betulae (Linnaeus, 1758) & Chermes betulae Linnaeus, 1758 & \\
\hline \multicolumn{3}{|l|}{ Psylla betulaenanae Ossiannilsson, 1970} \\
\hline \multicolumn{3}{|l|}{ Psylla betulibetuliae Li, 2011} \\
\hline *Psylla hartigii Flor, 1861 & & comb. rev. from Chamaepsylla \\
\hline \multicolumn{3}{|l|}{ Psylla huabeialnia Li, 2011} \\
\hline \multicolumn{3}{|l|}{$\begin{array}{l}\text { Psylla kotejai } \\
\text { Drohojowska \& Klimaszewski, } 2006\end{array}$} \\
\hline *Psylla striata Patch, 1911 & & comb. rev. from Cacopsylla \\
\hline \multicolumn{3}{|c|}{ Host: Carpinus } \\
\hline \multicolumn{3}{|l|}{ Psylla carpinicola Crawford, 1914} \\
\hline \multicolumn{3}{|c|}{ Host: Corylus } \\
\hline Psylla diloncha (Caldwell, 1938) & Psyllia diloncha Caldwell, 1938 & comb. rev. from Cacopsylla \\
\hline \multicolumn{3}{|c|}{ Host: Ostrya } \\
\hline *Psylla colorata Löw, 1888 & & comb. rev. from Baeopelma \\
\hline
\end{tabular}

\title{
Psyllidae incertae sedis
}

\section{Comments}

Klimaszewski (1997) erected the poorly diagnosed genera Indepsylla†, Parapsyllopsis $\dagger$ and Paropsylla $\dagger$ from Dominican amber. Burckhardt \& Ouvrard (2012) synonymised the first with Limbopsylla Brown \& Hodkinson, 1988 and the two others with Platycorypha Tuthill, 1945. A reevaluation of Limbopsylla and 
Table 4. Holarctic species in Psyllinae Latreille, 1807 associated with Buxus (Buxaceae) and Prunus (Rosaceae) referrable to Spanioneura Foerster, 1848. Taxa sampled in Percy et al. (2018) are indicated with an asterisk.

\begin{tabular}{|c|c|c|}
\hline Valid combination & Previous combinations & Comments \\
\hline \multicolumn{3}{|c|}{$\begin{array}{l}\text { Spanioneura Foerster, 1848: 94; = Asphagidella Enderlein, 1921: 120, type-species Chermes buxi Linnaeus, 1758, by origina } \\
\text { designation, syn. nov. }\end{array}$} \\
\hline \multicolumn{3}{|c|}{ Host: Buxus (Buxaceae) } \\
\hline *Spanioneura buxi (Linnaeus, 1758) & $\begin{array}{l}\text { Chermes buxi Linnaeus, 1758; Psylla buxi } \\
\text { (Linnaeus, 1758); Asphagidella buxi (Linnaeus, } \\
\text { 1758); Psylla (Asphagidella) buxi (Linnaeus, } \\
\text { 1758); Psylla (Baeopelma) buxi (Linnaeus, } \\
\text { 1758) }\end{array}$ & $\begin{array}{l}\text { comb. rev.; transferred by } \\
\text { Loginova (1964) }\end{array}$ \\
\hline Spanioneura chujoi (Miyatake, 1982) & Psylla chujoi Miyatake, 1982 & comb. nov. \\
\hline \multicolumn{3}{|l|}{ Spanioneura caucasica Loginova, 1968} \\
\hline \multicolumn{3}{|l|}{ *Spanioneura fonscolombii Foerster, 1848} \\
\hline \multicolumn{3}{|c|}{ Host: Prunus (Rosaceae) } \\
\hline Spanioneura longicauda (Konovalova, 1986) & Psylla longicauda Konovalova, 1986 & $\begin{array}{l}\text { transferred by Cho et al. } \\
(2019)\end{array}$ \\
\hline Spanioneura morimotoi (Miyatake, 1963) & Psylla morimotoi Miyatake 1963 & comb. nov. \\
\hline Spanioneura omogoensis (Miyatake, 1963) & Psylla omogoensis Miyatake, 1963 & comb. nov. \\
\hline $\begin{array}{l}\text { Spanioneura pechai } \\
\text { (Klimaszewski \& Lodos, 1977) }\end{array}$ & $\begin{array}{l}\text { Amblyrhina pechai } \\
\text { Klimaszewski \& Lodos, } 1977\end{array}$ & $\begin{array}{l}\text { transferred by Hodkinson } \\
\text { \& Hollis (1987) }\end{array}$ \\
\hline \multicolumn{3}{|l|}{$\begin{array}{l}\text { Spanioneura persica } \\
\text { Burckhardt \& Lauterer, } 1993\end{array}$} \\
\hline Spanioneura sanguinea (Provancher, 1872) & $\begin{array}{l}\text { Diraphia sanguinea Provancher, 1872; } \\
\text { Psylla sanguinea (Provancher, 1872) }\end{array}$ & comb. nov. \\
\hline $\begin{array}{l}\text { Spanioneura turkiana } \\
\text { (Klimaszewski \& Lodos, 1977) }\end{array}$ & $\begin{array}{l}\text { Amblyrhina turkiana } \\
\text { Klimaszewski \& Lodos, } 1977\end{array}$ & $\begin{array}{l}\text { transferred by Hodkinson } \\
\text { \& Hollis (1987) }\end{array}$ \\
\hline Spanioneura yasumatsui (Miyatake, 1963) & Psylla yasumatsui Miyatake, 1963 & comb. nov. \\
\hline Spanioneura ziozankeana (Kuwayama, 1908) & Psylla ziozankeana Kuwayama, 1908 & comb. nov. \\
\hline
\end{tabular}

Platycorypha suggests that they are not closely related to these two genera. Here, we reinstate the three genera as incertae sedis in the Psyllidae:

Indepsylla† Klimaszewski, 1996, stat. rev.

Parapsyllopsis† Klimaszewski, 1996, stat. rev.

Paropsylla† Klimaszewski, 1996, stat. rev.

Family *Triozidae Löw, 1879

Asiotriozinae Li, 2011: 1512.

Bactericerini Heslop-Harrison, 1958: 577-578.

Carsitriinae Li, 2011: 1303.

Epitriozini Kwon, 1983: 79.

Eutriozini Loginova, 1964: 473.

Hemischizocraniini Bekker-Migdisova, 1973: 115.

Leptinopterinae (sic) Bekker-Migdisova, 1973: 104.

Metatriozidinae Li, 2011: 1513.

Neolithinae White \& Hodkinson, 1985: 273.

Neotriozidae Li, 2011: 1307.

Paracomecini Bekker-Migdisova, 1973: 115. 
Pauropsyllinae Crawford, 1914: 42.

Rhinopsyllidae Klimaszewski, 1993: 65.

Siphonaleyrodinae Takahashi, 1932: 48.

Trichochermini Kwon, 1983: 82.

Triozopsinae Li, 2011: 1383.

\section{Comments}

With around 70 genera and over 1000 species (Ouvrard 2020), the Triozidae constitutes the second largest family of Psylloidea. Many of the genera are poorly defined and Trioza Foerster, 1848 with over 400 described species has long been recognised as polyphyletic (Hollis 1984). The molecular analyses confirm the polyphyly of Trioza and the artificial nature of genera such as Kuwayama Crawford, 1911. For a more stable and improved classification, most of the genera have to be redefined and several new genera have to be described to establish monophyletic clades, where no generic name is currently available. This task is beyond the scope of the present paper and awaits further studies.

\section{Included genera}

*Aacanthocnema Tuthill \& Taylor, 1955; Acanthocasuarina Taylor in Taylor et al. (2011); Afrotrioza Hollis, 1984; *Anomocephala Tuthill, 1942; Asiotrioza Li, 2011; *Bactericera Puton, 1876 (syn. Allotrioza, Carsitria, Eubactericera, Bactericera (Klimaszewskiella) replacement name for Smirnovia Klimaszewski nec Lučnic, Paratrioza, Rhinopsylla); *Baeoalitriozus Li, 2011; Berchemitrioza Li, 2011; *Calinda Blanchard, 1852; *Casuarinicola Taylor in Taylor et al. 2010; *Cecidotrioza Kieffer, 1908 (syn. Homotrioza); *Ceropsylla Riley, 1885; *Cerotrioza Crawford, 1918; Chouitrioza Li, 1989; Colopelma Enderlein, 1926; Conicotrioza Li, 2005; *Crawforda Caldwell, 1940; Dolichotrioza Li, 2002; *Dyspersa Klimaszewski, 1968; Egeirotrioza Boselli, 1931 (syn. Evegeirotrioza); Engytatoneura Loginova, 1972; Eotrioza Konovalova, 1987 (syn. Trachotrioza Li, 2011); Epitrioza Kuwayama, 1910; Eryngiofaga Klimaszewski, 1968; Eutrioza Loginova, 1964; Furcitrioza Li, 2011; Genotriozus Li, 2011; *Hemischizocranium Tuthill, 1956; *Hemitrioza Crawford, 1914; *Heterotrioza Dobreanu \& Manolache, 1960 (syn. Trioza (Halotrioza), Triozidus); *Hevaheva Kirkaldy, 1902; Hippophaetrioza Conci \& Tamanini, 1984 (syn. Hippophaetrioza (Maculatrioza)); Izpania Klimaszewski, 1962; *Kuwayama Crawford, 1911 (replacement name for Epitrioza Crawford nec Kuwayama, syn. Succinopsylla†); *Lauritrioza Conci \& Tamanini, 1986; *Leptotrioza Miyatake, 1972; *Leptynoptera Crawford, 1919; *Leuronota Crawford, 1914 (syn. Paracomeca); Levidea Tuthill, 1938; *Megatrioza Crawford, 1915; Metatrioza Tuthill, 1939; Myotrioza Taylor, in Taylor et al. 2016; Neolithus Scott, 1882; Neotrioza Kieffer, 1905; Neotriozella Crawford, 1911 (replacement name for Neotrioza Crawford nec Kieffer); Nothotrioza Burckhardt in Carneiro et al., 2013; Ozotrioza Kieffer, 1905; Parastenopsylla Yang, 1984 (syn. Indotrioza); *Pariaconus Enderlein, 1926; *Pauropsylla Rübsaamen, 1899 (syn. Neotrioza sensu Li, 2011 nec Kieffer, 1905, misinterpretation, Sympauropsylla); Paurotriozana Caldwell, 1940; Petalolyma Scott, 1882; *Phylloplecta Riley, 1884 (syn. Choricymoza, Sinitrioza); *Powellia Maskell, 1879; Pseudotrioza Miyatake, 1972; Rhegmoza Enderlein, 1918; Rhinopsyllida† Klimaszewski, 1997; *Schedoneolithus Tuthill, 1959; *Schedotrioza Tuthill \& Taylor, 1955; Siphonaleyrodes Takahashi, 1932; *Spanioza Enderlein, 1926; *Stenopsylla Kuwayama, 1910 (syn. Cryptotrioza, Dasymastix, Eustenopsylla, Philippinocarsia); *Stevekenia Percy, 2017; *Swezeyana Caldwell, 1940; Torulus Li, 1991; *Trichochermes Kirkaldy, 1904 (replacement name for Trichopsylla Thomson nec Kolenati); Trioacantha† Klimaszewski, 1998; *Trioza Foerster, 1848 (syn. Metatriozidus, Triozopsis); *Triozoida Crawford, 1911 (syn. Myrmecephala, Optomopsylla); Trisetitrioza Li, 1995 (syn. Neorhinopsylla). 
BURCKHARDT D. et al., Updated classification of the jumping plant-lice

\section{Psylloidea incertae sedis}

\section{Nomina dubia}

Labicria Enderlein, 1918: 348; type-species: Labicria barbata Enderlein, 1918 by original designation and monotypy.

\section{Comments}

The type of the Brazilian Labicria barbata is destroyed (D. Burckhardt, unpubl.) and we have not seen any fresh material fitting the original description.

\section{Unavailable names}

Cephalopsyllini Heslop-Harrison, 1960: 160; nomen nudum, no included genera.

Stigmaphalarini Vondráček, 1957: 140; nomen nudum, no included genera; syn. of Aphalarini Löw, 1879.

Dentotriza Park \& Taylor, 1996a: 177; nomen nudum, no included species.

Hispaniola Ramírez Gómez, 1956: 76; nomen nudum, type species not designated; syn. of Arytainilla Loginova, 1972.

Lindbergia Heslop-Harrison, 1951: fig. 2a-b; nomen nudum, no included species, syn. of Arytainilla Loginova, 1972.

Lindbergiella Heslop-Harrison, 1961: 509; nomen nudum, type species not designated; syn. of Arytainilla Loginova, 1972.

Loginoviana Mathur, 1975: 230; nomen nudum, no type designated and no description; syn. of Ctenarytaina Ferris \& Klyver, 1932.

Metapaurocephala Heslop-Harrison, 1952: 966; nomen nudum, no type designated.

Neoacizzia Park \& Taylor, 1996b: 177; nomen nudum, no included species; syn. of Acizzia HeslopHarrison, 1961.

Parapaurocephala Heslop-Harrison, 1952: 962; nomen nudum, no description; syn. of Microphyllurus Li, 2002.

Paraphyllolyma Heslop-Harrison, 1952: 966; nomen nudum, no type designated.

Peltapaurocephala Heslop-Harrison, 1952: 966; nomen nudum, no description; syn. of Padaukia Hollis \& Martin, 1993.

Pennapsylla Froggatt, 1923: pl. 2, fig. 11, nomen nudum, no type designated; syn. of Cardiaspina Crawford, 1911.

Phacopteronella Heslop-Harrison, 1960: 504; nomen nudum, no description, no type designated.

Pseudotingidiforma Heslop-Harrison, 1952: 966; nomen nudum, no type designated; syn. of Lisronia Loginova, 1976.

Psyllia Kirkaldy, 1905: 268; nomen nudum, no description; syn. of Cacopsylla Ossiannilsson, 1970.

Tingidiforma Heslop-Harrison, 1951: 27; nomen nudum; syn. of Togepsylla Kuwayama, 1931.

\section{Nomenclatorial acts and changes}

\section{New taxa}

Amorphicolinae subfam. nov. 
Katacephalinae subfam. nov.

Microphyllurinae subfam. nov.

Neophyllurinae subfam. nov.

Platycoryphinae subfam. nov.

Hollisiana gen. nov.

\section{New synonymies}

Psyllinae Latreille, 1807 = Cornopsyllini Li, 2011, syn. nov.

Ceanothia Heslop-Harrison, 1961 = Euglyptoneura Heslop-Harrison, 1961, syn. nov.

Colophorina Capener, 1973 = Otroacizzia $\dagger$ Klimaszewski, 1996, syn. nov.

Lisronia Loginova, 1976 = Pseudotingidiforma Heslop-Harrison, 1952, nomen nudum, syn. nov.

Acizzia Heslop-Harrison, 1961 = Neoacizzia Park \& Taylor, 1996b, nomen nudum, syn. nov.

Psylla Geoffroy, 1762 = Baeopelma Enderlein, 1926, syn. nov.

Psylla Geoffroy, 1762 = Chamaepsylla Ossiannilsson, 1970, syn. nov.

Psylla Geoffroy, 1762 = Psylla (Labyrinthopsylla) Ossiannilsson, 1970, syn. nov.

Spanioneura Foerster, 1848 = Asphagidella Enderlein, 1921, syn. nov.

\section{New combinations}

Ceanothia fuscipennis (Crawford, 1914) comb. nov. from Arytaina

Ceanothia minuta (Crawford, 1914) comb. nov. from Arytaina

Ceanothia robusta (Crawford, 1914) comb. nov. from Arytaina

Colophorina muta $\dagger$ (Klimaszewski, 1996) comb. nov. from Otroacizzia $\dagger$

Euryconus prosapia $\dagger$ (Klimaszewski, 1996) comb. nov. from Otroacizzia $\dagger$

Euryconus soriae† (Peñalver \& García-Gimeno, 2006) comb. nov. from Otroacizzia †

Euryconus tertia $\dagger$ (Klimaszewski, 1996) comb. nov. from Otroacizzia†

Hollisiana caradociforma (Brown \& Hodkinson, 1988) gen. et comb. nov. from Limbopsylla

Hollisiana nigrivenis (Brown \& Hodkinson, 1988) gen. et comb. nov., from Limbopsylla

Microphyllurus longicellus (Tuthill, 1943) comb. nov. from Paurocephala

Purshivora aculeata (Crawford, 1914) comb. nov. from Arytaina

Purshivora acuminata (Jensen, 1956) comb. nov. from Psylla

Purshivora adusta (Tuthill, 1937) comb. nov. from Euphalerus

Purshivora brevistigmata (Patch, 1912) comb. nov. from Psylla

Purshivora cercocarpi (Jensen, 1957) comb. nov. from Euphalerus

Purshivora coryli (Patch, 1912) comb. nov. from Psylla

Purshivora difficilis (Tuthill, 1943) comb. nov. from Psylla

Purshivora hirsuta (Tuthill, 1938) comb. nov. from Arytaina 
Purshivora idahoensis (Jensen, 1946) comb. nov. from Euphalerus

Purshivora insignita (Tuthill, 1943) comb. nov. from Psylla

Purshivora magna (Crawford, 1914) comb. nov. from Psylla

Purshivora maculata (Crawford, 1914) comb. nov. from Psylla

Purshivora media (Tuthill, 1943) comb. nov. from Psylla

Purshivora minuta (Crawford, 1914) comb. nov. from Psylla

Purshivora nigranervosa (Jensen, 1956) comb. nov. from Psylla

Purshivora tantilla (Tuthill, 1937) comb. nov. from Euphalerus

Spanioneura chujoi (Miyatake, 1982) comb. nov. from Psylla

Spanioneura morimotoi (Miyatake, 1963) comb. nov. from Psylla

Spanioneura omogoensis (Miyatake, 1963) comb. nov. from Psylla

Spanioneura sanguinea (Provancher, 1872) comb. nov. from Diraphia

Spanioneura ziozankeana (Kuwayama, 1908) comb. nov. from Psylla

Telmapsylla lagunculariae (Brown \& Hodkinson, 1988) comb. nov. from Limbopsylla

\section{Revived combinations}

Psylla colorata Löw, 1888 comb. rev. from Baeopelma

Psylla diloncha (Caldwell, 1938) comb. rev. from Cacopsylla

Psylla foersteri Flor, 1861 comb. rev. from Baeopelma

Psylla hartigii Flor, 1861 comb. rev. from Chamaepsylla

Psylla striata Patch, 1911 comb. rev. from Cacopsylla

Spanioneura buxi (Linnaeus, 1758), comb. rev. from Psylla

\section{Replacement name}

Microphyllurus lii, nom. nov. for Microphyllurus longicellus Li, 2002, nec Tuthill (1943a)

\section{New and revived status}

Family Mastigimatidae Bekker-Migdisova, 1973, stat. nov.

Subfamily Cecidopsyllinae Li, 2011, stat. rev. et nov.

Subfamily Homotominae Heslop-Harrison, 1958, stat. rev.

Subfamily Phacopteroninae Heslop-Harrison, 1958, stat. nov.

Tribe Ctenarytainini White \& Hodkinson, 1985, stat. rev.

Tribe Dynopsyllini Bekker-Migdisova, 1973, stat. rev.

Tribe Homotomini Heslop-Harrison, 1958, stat. rev.

Tribe Macrohomotomini White \& Hodkinson, 1985, stat. rev.

Subtribe Diceraopsyllina Hollis \& Broomfield, 1989, stat. nov.

Subtribe Dynopsyllina Bekker-Migdisova, 1973, stat. rev. 
Subtribe Edenina Bhanotar, Ghosh \& Ghosh, 1972, stat. nov.

Subtribe Macrohomotomina White \& Hodkinson, 1985, stat. nov.

Subtribe Homotomina Heslop-Harrison, 1958, stat. nov.

Subtribe Phytolymina White \& Hodkinson, 1985, stat. nov.

Subtribe Synozina Bekker-Migdisova, 1973, stat. nov.

Indepsylla $\dagger$ Klimaszewski, 1996, stat. rev.

Microphyllurus Li, 2002, stat. rev.

Parapsyllopsis $\dagger$ Klimaszewski, 1996, stat. rev.

Paropsylla† Klimaszewski, 1996, stat. rev.

Primascena† Klimaszewski, 1998, stat. rev.

\section{Discussion}

The revised classification presented here is similar to that of Burckhardt \& Ouvrard (2012) but with some notable differences. The Carsidaridae, Homotomidae, Phacopteronidae and Triozidae remain unchanged in terms of circumscription and content but the first three are sunk to subfamilies. Also, the circumscription of the following well-defined subfamilies is identical in the two classifications: Aciziinae, Aphalarinae, Atmetocraniinae, Calophyinae, Liviinae, Metapsyllinae, Pachypsyllinae, Rhinocolinae, Spondyliaspidinae, Symphorosinae and Togepsyllinae. Their assignment to families remains unchanged except for Pachypsyllinae which is transferred from Aphalaridae to Carsidaridae, along with Homotomidae which is sunk to subfamily. From the Calophyidae of Burckhardt \& Ouvrard (2012), the Mastigimatinae is removed and given family status, except for Cecidopsylla which is assigned to the Cecidopsyllinae within Aphalaridae. The most fundamental change concerns the Diaphorinini (Euphyllurinae) of Burckhardt \& Ouvrard (2012), representing a polyphyletic assemblage of 13 genera. Apart from Megadicrania, Peripsyllopsis and Psyllopsis, which remain in Euphyllurinae, all genera are transferred to Psyllidae: Caradocia, Epipsylla and Geijerolyma to Ciriacreminae, Cornopsylla to Psyllinae, Diaphorina and Parapsylla to Diaphorininae and Lautereropsis, Katacephala, Notophorina and Tuthillia to Katacephalinae subfam. nov. Microphyllurus is removed from synonymy with Peripsyllopsis and moved as a separate subfamily to Aphalaridae. The Euphyllurinae as conceived here, is not further subdivided into tribes, but includes the three genera mentioned above and the constituent of the tribes Euphyllurini, Pachypsylloidini and Strophingiini of Burckhardt \& Ouvrard (2012), but with Neophyllura removed into a separate subfamily. The Psyllidae as defined here differ from the previous concept in the addition of Diaphorininae and Katacephalinae subfam. nov. as well as slightly changed subfamily circumscriptions. The Amorphicolinae subfam. nov. and Platycoryphinae subfam. nov. are separated from Psyllinae, and a few genera and species are moved between subfamilies.

Future research should address the following aspects. The monophyly of the weakly supported family level taxa and weakly supported or unresolved relationships between these should be tested by including additional informative taxa not previously included and by analysing additional genes. The current placement of some taxa not previously included in the molecular analyses should be tested such as the placement of the Atmetocraniinae, Metapsyllinae and Symphorosinae in the Calophyidae; that of Caradocia, Epipsylla and Geijerolyma in the Ciriacreminae; that of Lautereropsis, Notophorina and Tuthillia in the Katacephalinae subfam. nov.; as well as that of Allophorina, Limbopsylla and Padaukia in the Platycoryphinae subfam. nov. In Psyllinae, several genera are poorly defined and more morphological and molecular work is required. The internal classification of Triozidae is not addressed here, as the entire generic classification of the family needs to be reexamined, a task beyond the scope of this paper. Finally, many new species and genera represented in collections (BMNH, MHNG, NHMB, 
BURCKHARDT D. et al., Updated classification of the jumping plant-lice

USNM, etc.) await description and poorly known faunas, such as the Afrotropical and Neotropical regions, should be explored with targeted field work.

\section{Acknowledgments}

We thank Piotr Naskrecki and Kenji Nishida for providing spectacular photos of immatures of Hollisiana sp. from Costa Rica. For constructive and helpful comments on the manuscript we are grateful to Ian D. Hodkinson, Igor Malenovský and Gary S. Taylor.

\section{References}

Bekker-Migdisova E.E. 1973. Sistema psillomorf (Psyllomorpha) i polozheriie gruppy v otryade ravnokrylykh (Homoptera). In: Narchuk E.P. (ed.) Doklady na dvadzat chetvertom escheghodnom chtenii pamyati N. A. Kholodovskogo: 90-118. Nauka, Leningrad. [In Russian.]

Bliven B.P. 1956. New Hemiptera from the western States with Illustrations of previously described Species and new Synonymy in the Psyllidae. Published by the author, Eureka.

Bliven B.P. 1958. Studies on insects of the redwood empire II: New Hemiptera and further notes on the Colladonus complex. Occidental Entomologist 1: 8-24.

Brown R.G. \& Hodkinson I.D. 1988. Taxonomy and Ecology of the jumping Plant-Lice of Panama (Homoptera: Psylloidea). E.J. Brill/Scandinavian Science Press Ltd, Leiden.

Burckhardt D. 1987. Jumping plant lice (Homoptera: Psylloidea) of the temperate Neotropical region. Part 1: Psyllidae (subfamilies Aphalarinae, Rhinocolinae and Aphalaroidinae). Zoological Journal of the Linnean Society 89: 299-392. https://doi.org/10.1111/j.1096-3642.1987.tb01568.x

Burckhardt D. 1991a. Boreioglycaspis and spondyliaspidine classification (Homoptera: Psylloidea). Raffles Bulletin of Zoology 39: 15-52.

Burckhardt D. 1991b. Notes on the indo-australian plant louse genus Cecidopsylla (Homoptera, Psylloidea) with description of two new species. Phytophaga 3: 73-86.

Burckhardt D. 2005. Ehrendorferiana, a new genus of Neotropical jumping plant lice (Insecta: Hemiptera: Psylloidea) associated with conifers (Cupressaceae). Organisms Diversity \& Evolution 5: 317-319. https://doi.org/10.1016/j.ode.2005.08.001

Burckhardt D. 2017. Der geheimnisvolle Zapfenzieher-Blattfloh. In: Füglister K.M., Hicklin M. \& Mäser P. (eds) Natura obscura, 200 Naturforschende - 200 Naturphänomene - 200 Jahre Naturforschende Gesellschaft in Basel: 34. Schwabe Verlag, Basel.

Burckhardt D. \& Basset Y. 2000. The jumping plant-lice (Hemiptera, Psylloidea) associated with Schinus (Anacardiaceae): systematics, biogeography and host plant relationships. Journal of Natural History 34: 57-155. https://doi.org/10.1080/002229300299688

Burckhardt D. \& Lauterer P. 1989. Systematics and biology of the Rhinocolinae (Homoptera: Psylloidea). Journal of Natural History 23: 643-712. https://doi.org/10.1080/00222938900770371

Burckhardt D. \& Mifsud D. 2003. Jumping plant-lice of the Paurocephalinae (Insecta, Hemiptera, Psylloidea): systematics and phylogeny. Contributions to Natural History (Bern) 2: 3-34.

Burckhardt D. \& Ouvrard D. 2012. A revised classification of the jumping plant-lice (Hemiptera: Psylloidea). Zootaxa 3509 (1): 1-34. https://doi.org/10.11646/zootaxa.3509.1.1

Burckhardt D. \& Poinar G. 2019. The first jumping plant-louse from mid-Cretaceous Burmese amber and its impact on the classification of Mesozoic psylloids (Hemiptera: Sternorrhyncha: Psylloidea s. 1.). Cretaceous Research 106: 104240. https://doi.org/10.1016/j.cretres.2019.104240 
Burckhardt D. \& Queiroz D.L. 2013. Phylogenetic relationships within the subfamily Aphalarinae including a revision of Limataphalara (Hemiptera: Psylloidea: Aphalaridae). Acta Musei Moraviae, Scientiae biologicae 98: 35-56.

Burckhardt D. \& Queiroz D.L. 2017. The jumping plant-lice of the Neotropical genus Tainarys (Hemiptera: Psylloidea) associated with Anacardiaceae. Zootaxa 4232 (4): 535-567. https://doi.org/10.11646/zootaxa.4232.4.5

Burckhardt D. \& Queiroz D.L. 2020. Neotropical jumping plant-lice (Hemiptera, Psylloidea) associated with plants of the tribe Detarieae (Leguminosae, Detarioideae). Zootaxa 4733 (1): 1-73.

https://doi.org/10.11646/zootaxa.4733.1.1

Burckhardt D., Cho G. \& Lee S. 2018a. Moriphila furva gen. and sp. nov. (Hemiptera: Psylloidea: Homotomidae), a new jumping plant-louse from Korea associated with Morus australis (Moraceae). Zootaxa 4444 (3): 299-315. https://doi.org/10.11646/zootaxa.4444.3.5

Burckhardt D., Sharma A. \& Raman A. 2018b. Checklist and comments on the jumping plant-lice (Hemiptera: Psylloidea) from the Indian subcontinent. Zootaxa 4457 (1): 1-38.

https://doi.org/10.11646/zootaxa.4457.1.1

Cho G., Malenovsky I. \& Lee S. 2019. Higher-level molecular phylogeny of jumping plant lice (Hemiptera: Sternorrhyncha: Psylloidea). Systematic Entomology 44 (3): 638-651.

https://doi.org/10.1111/syen.12345

Crawford D.L. 1914. A monograph of the jumping plant-lice or Psyllidae of the New world. Bulletin of the United States National Museum 85: 1-186. https://doi.org/10.5479/si.03629236.85.1

Drohojowska J. 2015. Thorax Morphology and its Importance in establishing Relationships within Psylloidea (Hemiptera, Sternorrhyncha). Wydawnictwo Uniwersytetu Śląskiego, Katowice.

Drohojowska J., Szwedo J., Müller P. \& Burckhardt D. 2020. New fossil from mid-Cretaceous Burmese amber confirms monophyly of Liadopsyllidae (Hemiptera: Psylloidea). Scientific Reports 10:17607: 9 pages.

Froggatt W.W. 1923. Forest Insects of Australia. Forestry Commissioners of New South Wales, Government Printer, Sydney, Australia.

Hanson P.E. \& Nishida K. 2016. Insects and Other Arthropods of Tropical America. Comstock Publishing Associates, Ithaca.

Heslop-Harrison G. 1952. The genus Rhinocola Förster and associated genera of the Aphalarinae.-I. Annals and Magazine of Natural History Series 12 5: 957-974. https://doi.org/10.1080/00222935208654375

Heslop-Harrison G. 1958. Subfamily separation in the Homopterous Psyllidae-III (a-c). Annals and Magazine of Natural History Series 13 1: 561-579. https://doi.org/10.1080/00222935808650984

Heslop-Harrison G. 1961. The Arytainini of the subfamily Psyllinae, Hemiptera-Homoptera, family Psyllidae. -II. Annals and Magazine of Natural History Series 13 3: 417-439.

https://doi.org/10.1080/00222936008651037

Hodkinson I.D. 1988. The Nearctic Psylloidea (Insecta: Homoptera): an annotated check list. Journal of Natural History 22: 1179-1243. https://doi.org/10.1080/00222938800770751

Hodkinson I.D. 1990. A new species of Syncoptozus Enderlein from Mexico with a redefinition of the subfamily Togepsyllinae Bekker-Migdisova (Insecta: Homoptera: Psylloidea). Journal of Natural History 24: 711-717. https://doi.org/10.1080/00222939000770491

Hodkinson I.D. \& Hollis D. 1987. The legume-feeding psyllids (Homoptera) of the west Palaearctic region. Bulletin of the British Museum (Natural History) Entomology series 56: 1-86. 
Hollis D. 1984. Afrotropical jumping plant lice of the family Triozidae (Homoptera: Psylloidea). Bulletin of the British Museum (Natural History) Entomology series 49: 1-102.

Hollis D. 1987. A review of the Malvales-feeding psyllid family Carsidaridae (Homoptera). Bulletin of the British Museum (Natural History) Entomology series 56: 87-127.

Hollis D. 2004. Australian Psylloidea. Jumping Plantlice and lerp Insects. Australian Biological Resources Study, Canberra.

Hollis D. \& Broomfield P.S. 1989. Ficus-feeding psyllids (Homoptera), with special reference to the Homotomidae. Bulletin of the British Museum (Natural History) Entomology series 58: 131-183.

Hollis D. \& Martin J.H. 1997. Jumping plantlice (Insecta: Hemiptera) attacking Lonchocarpus species (Leguminosae), including 'Black Cabbaga Bark', in Belize. Journal of Natural History 31: 237-267. https://doi.org/10.1080/00222939700770131

International Commission on Zoological Nomenclature. 1965. Opinion 731. Psylla Geoffroy, 1762 (Insecta, Hemiptera): validated under the plenary powers with suppression of Chermes Linnaeus, 1758. Bulletin of Zoological Nomenclature 22: 86-87.

International Commission on Zoological Nomenclature. 1999. International Code of Zoological Nomenclature. The International Trust for Zoological Nomenclature, London.

International Commission on Zoological Nomenclature. 2012. Amendment of Articles 8, 9, 10, 21 and 78 of the International Code of Zoological Nomenclature to expand and refine methods of publication. ZooKeys 219: 1-10. https://doi.org/10.3897/zookeys.219.3944

Jensen D.D. 1956. New species of Psylla from western United States and biological notes (Homoptera: Psyllidae). Canadian Entomologist 88: 101-109. https://doi.org/10.4039/Ent88101-3

Jensen D.D. 1957a. A new genus and five new species of Psyllidae from California and Lower California (Homoptera). Wasmann Journal of Biology 15: 15-34.

Jensen D.D. 1957b. Four new species of Arytaina from California (Homoptera: Psyllidae). Journal of the Kansas Entomological Society 30: 89-98.

Kieffer J.J. 1906. Eine neue gallenerzeugende Psyllide aus Vorderindien. Zeitschrift für wissenschaftliche Insektenbiologie 2: 387-390.

Kirkaldy G.W. 1905. Neue und wenig bekannte Hemiptera. Wiener Entomologische Zeitung 24: 266268.

Klimaszewski S.M. 1963. Eine neue Art der Unterfamilie Ciriacreminae aus Korea (Homoptera, Psyllidae). Bulletin de l'Académie polonaise des Sciences. Classe II 11: 91-94.

Klimaszewski S.M. 1993. The structure of hind wings in Psyllodea (Homoptera) and its possible significance in recognizing the relationships within this suborder. Acta Biologica Silesiana 22: 57-68.

Klimaszewski S.M. 1996. New psyllids (Homoptera, Psylloidea) from Dominican amber. Acta Biologica Silesiana 29: 24-44.

Klimaszewski S.M. \& Popov Y. 1993. New fossil hemipteran insects from Southern England (Hemiptera: Psyllina+Coleorrhyncha). Annals of the Upper Silesian Museum, Entomology, Supplement-Rocznik Muzeum Gornoslaskiego, Entomologia, Suplement 1: 13-36.

Kwon Y.J. 1983. Psylloidea of Korea (Homoptera: Sternorrhyncha). Editorial committee of Insecta Koreana, Seoul. 
Labina E.S., Maryańska-Nadachowska A., Burckhardt D. \& Kuznetsova V.G. 2014. Variation in sperm formation patterns in jumping plant-lice (Hemiptera: Psylloidea): a light microscopic study. Folia Biologica-Krakow 62: 321-333. https://doi.org/10.3409/fb62_4.321

Li F. 2002. Homoptera: Psylloidea. In: Huang F.-S., Yin H., Zeng R., Lin M. \& Gu M. (eds) Forest Insects of Hainan: 171-189. Science Press, Beijing.

Li F. 2011. Psyllidomorpha of China (Insecta: Hemiptera). Science Press, Beijing.

Loginova M.M. 1964. Podotrjad Psyllinea. In: Bei-Bienko G.Y.(ed.) Opredelitel nasekomykh Evropeiskoi chasti SSSR: 437-482. Izdatel'stvo Nauka, Moscow.

Loginova M.M. 1973. Taxonomy of the tribe Euphyllurini (Psyllidae, Homoptera). Zoologicheskii Zhurnal 52: 858-869.

Loginova M.M. 1974. Jumping plant lice of the tribe Stigmaphalarini Vondr. (Psylloidea, Aphalaridae) from arid regions of the Palearctic. Entomologicheskoe Obozrenie 53: 150-170.

Loginova M.M. 1976. A classification of the subfamily Arytaininae Crawf. (Homoptera, Psyllidae). 1. A review of the genera of the tribe Arytainini. Entomologicheskoe Obozrenie 55: 589-601.

Luo X., Li Q., Li F. \& Cai W. 2013. A revision of the endemic Chinese genus Cornopsylla (Hemiptera: Psyllidae), with potential pests on Zanthoxylum (Rutaceae). Zootaxa 3646 (2): 127-148.

https://doi.org/10.11646/zootaxa.3646.2.2

Luo X., Cai W. \& Qiao G. 2017. Half-jumping plant lice - a taxonomic revision of the distinctive psyllid genus Togepsylla Kuwayama with a reassessment of morphology (Hemiptera, Psylloidea). ZooKeys 716: 63-93. https://doi.org/10.3897/zookeys.716.13916

Mathur R.N. 1975. Psyllidae of the Indian Subcontinent. Indian Council of Agricultural Research, New Delhi.

Muddiman S.B., Hodkinson I.D. \& Hollis D. 1992. Legume-feeding psyllids of the genus Heteropsylla (Homoptera: Psylloidea). Bulletin of Entomological Research 82: 73-117.

https://doi.org/10.1017/S0007485300051518

Ouvrard D. 2002. Systématique phylogénétique des Hemiptera Psylloidea: morphologie comparée du thorax et structures secondaires de l'ARNr 18S. Bulletin de la Société zoologique de France 127: 345357.

Ouvrard D. 2020. Psyl'list - The World Psylloidea Database.

Available from http://www.hemiptera-databases.com/psyllist [accessed 19 Jun. 2020].

https://doi.org/10.5519/0029634

Ouvrard D., Burckhardt D., Azar D. \& Grimaldi D. 2010. Non-jumping plant-lice in Cretaceous amber (Hemiptera: Sternorrhyncha: Psylloidea). Systematic Entomology 35: 172-180.

https://doi.org/10.1111/j.1365-3113.2009.00499.x

Ouvrard D., Burckhardt D. \& Greenwalt D. 2013. The oldest jumping plant-louse (Insecta: Hemiptera: Sternorrhyncha) with comments on the classification and nomenclature of the Palaeogene Psylloidea. Acta Musei Moraviae 98: 21-33.

Ouvrard D., Chalise P. \& Percy D.M. 2015. Host-plant leaps versus host-plant shuffle: a global survey reveals contrasting patterns in an oligophagous insect group (Hemiptera, Psylloidea). Systematics and Biodiversity 13: 434-454. https://doi.org/10.1080/14772000.2015.1046969

Park H.C. \& Taylor K.L. 1996a. A new genus of family Triozidae from Australia (Homoptera: Psylloidea). Korean Journal of Applied Entomology 35: 177. 
Park H.C. \& Taylor K.L. 1996b. Revision of legume related genus Acizzia (Homoptera: Psylloidea). Korean Journal of Applied Entomology 35: 176-177.

Peñalver E. \& García-Gimeno V. 2006. Otroacizzia soriae sp. nov., a new Miocene psyllid (Insecta, Hemiptera, Psyllidae) from Dominican amber. Estudios Geológicos 62: 199-204.

https://doi.org/10.3989/egeol.0662119

Percy D.M. 2003. Radiation, diversity, and host-plant interactions among island and continental legumefeeding psyllids. Evolution 57: 2540-2556. https://doi.org/10.1554/02-558

Percy D.M., Rung A. \& Hoddle M.S. 2012. An annotated checklist of the psyllids of California (Hemiptera: Psylloidea). Zootaxa 3193: 1-27. https://doi.org/10.11646/zootaxa.3193.1.1

Percy D.M., Crampton-Platt A., Sveinsson S., Lemmon A.R., Lemmon E.M., Ouvrard D. \& Burckhardt D. 2018. Resolving the psyllid tree of life: phylogenomic analyses of the superfamily Psylloidea (Hemiptera). Systematic Entomology 43: 762-776. https://doi.org/10.1111/syen.12302

Ramírez Gómez C. 1956. Los Psilidos de España. Boletín de la Real Sociedad Española de Historia Natural (Secc. Biol.) 54: 63-106.

Scott J. 1882. On certain genera and species of the group of Psyllidae in the collection of the British Museum. Transactions of the Entomological Society of London 1882: 449-473. https://doi.org/10.1111/j.1365-2311.1882.tb01583.x

Szwedo J., Drohojowska J., Popov Y.A., Simon E. \& Wegierek P. 2019. Aphids, true hoppers, jumping plant-lice, scale insects, true bugs and whiteflies (Insecta: Hemiptera) from the Insect Limestone (latest Eocene) of the Isle of Wight, UK. Earth and Environmental Science Transactions of the Royal Society of Edinburgh 110: 331-396. https://doi.org/10.1017/S175569101900001X

Takahashi R. 1932. Aleyrodidae of Formosa. Part I. Report Department of Agriculture Government Research Institute Formosa Taihoku 59: 1-57.

Taylor K.L. 1990. The tribe Ctenarytainini (Hemiptera: Psylloidea): a key to known Australian genera, with new species and two new genera. Invertebrate Systematics 4: 95-121.

https://doi.org/10.1071/IT9900095

Tuthill L.D. 1943a. Descriptions and records of some Fijian Psyllidae (Homoptera). Occasional papers of Bernice P. Bishop Museum Honolulu, Hawaii 17: 221-228.

Tuthill L.D. 1943b. The Psyllids of America north of Mexico (Psyllidae: Homoptera) (Subfamilies Psyllinae and Triozinae). Iowa State College Journal of Science 17: 443-667.

Vondráček K. 1951. Jumping plant-lice in the collections of the Moravian Museum (Brno). Melichar's collection revised, part I. Acta musei Moraviae (Scientiae naturales) 36: 123-129.

Vondráček K. 1957. Mery-Psylloidea (Fauna ČSR, Svazek 9). Československá Akademie Věd, Praha.

Vondráček K. 1963. Jumping plant-lice (Psylloidea - Homoptera) of Central Africa. Part I (Congo). Acta Entomologica Musei Nationalis Pragae 35: 263-290.

White I.M. \& Hodkinson I.D. 1985. Nymphal taxonomy and systematics of Psylloidea (Homoptera). Bulletin of the British Museum (Natural History) Entomology 50: 153-301.

Yang M.-M., Burckhardt D. \& Fang S.J. 2009. Psylloidea of Taiwan, Volume I, Families Calophyidae, Carsidaridae, Homotomidae and Phacopteronidae, with Overview and Keys to Families and Genera of Taiwanese Psylloidea (Insecta: Hemiptera). National Chung Hsing University, Taichung.

Yang C.K. \& Li F. 1981. On the new subfamily Hemipteripsyllinae (Homoptera: Sternorrhyncha). Entomotaxonomia 3: 179-189. 
Manuscript received: 7 July 2020

Manuscript accepted: 10 December 2020

Published on: 5 March 2021

Topic editor: Nesrine Akkari

Desk editor: Kristiaan Hoedemakers

Printed versions of all papers are also deposited in the libraries of the institutes that are members of the EJT consortium: Muséum national d'histoire naturelle, Paris, France; Meise Botanic Garden, Belgium; Royal Museum for Central Africa, Tervuren, Belgium; Royal Belgian Institute of Natural Sciences, Brussels, Belgium; Natural History Museum of Denmark, Copenhagen, Denmark; Naturalis Biodiversity Center, Leiden, the Netherlands; Museo Nacional de Ciencias Naturales-CSIC, Madrid, Spain; Real Jardín Botánico de Madrid CSIC, Spain; Zoological Research Museum Alexander Koenig, Bonn, Germany; National Museum, Prague, Czech Republic.

Supp. file 1: The data of specimens illustrated on Figs 2-3, 5-8.

https://doi.org/10.5852/ejt.2021.736.1257.3703 